\title{
Application of engineered extracellular vesicles for targeted tumor therapy
}

\author{
Fusheng Zhang ${ }^{\dagger}$, Jinshuai Guo ${ }^{\dagger}$, Zhenghou Zhang, Meiqi Duan, Guang Wang, Yiping Qian, Haiying Zhao,
} Zhi Yang ${ }^{*}$ and Xiaofeng Jiang ${ }^{*}$ (D)

\begin{abstract}
All cells, including prokaryotes and eukaryotes, could release extracellular vesicles (EVs). EVs contain many cellular components, including RNA, and surface proteins, and are essential for maintaining normal intercellular communication and homeostasis of the internal environment. EVs released from different tissues and cells exhibit excellent properties and functions (e.g., targeting specificity, regulatory ability, physical durability, and immunogenicity), rendering them a potential new option for drug delivery and precision therapy. EVs have been demonstrated to transport antitumor drugs for tumor therapy; additionally, EVs' contents and surface substance can be altered to improve their therapeutic efficacy in the clinic by boosting targeting potential and drug delivery effectiveness. EVs can regulate immune system function by affecting the tumor microenvironment, thereby inhibiting tumor progression. Codelivery systems for EVs can be utilized to further improve the drug delivery efficiency of EVs, including hydrogels and liposomes. In this review, we discuss the isolation technologies of EVs, as well as engineering approaches to their modification. Moreover, we evaluate the therapeutic potential of EVs in tumors, including engineered extracellular vesicles and EVs'co-delivery systems.
\end{abstract}

\section{Highlights}

1. Technologies such as microfluidics can improve EVs isolation efficiency.

2. Engineering technologies can improve EVs drug loading efficiency and tumor targeting.

3. EVs-based drug co-delivery systems are being developed, such as those with liposomes and hydrogels.

Keywords: Extracellular vesicles, Drug delivery system, Targeted tumor therapy, Mesenchymal stem cells

\section{Introduction}

Tumors have been responsible for numerous deaths in the last decades. Owing to high recurrence and mortality rates, drug resistance, metastatic ability, and poor prognosis, they continue to pose a serious threat to human health [1]. Despite the immense advances

*Correspondence: yangzhi0910@163.com; 18900912171@163.com ${ }^{\dagger}$ Fusheng Zhang and Jinshuai Guo contributed equally to this work Department of General Surgery, Fourth Affiliated Hospital of China Medical University, Shenyang, China in medical technology over the years, the clinical outcomes of tumor treatment remain unsatisfactory, owing mainly to the lack of site-specific drug targeting capacity, which results in suboptimal chemotherapeutic outcomes [2]. Although chemotherapy is one of the main treatments for tumors, it also has significant limitations, including low delivery efficiency, tissue resistance, and insufficient drug targeting ability [3]. Additionally, low permeability and poor bioavailability in body fluids also limit the efficacy of chemotherapeutic drugs. These observations highlight the urgent original author(s) and the source, provide a link to the Creative Commons licence, and indicate if changes were made. The images or other third party material in this article are included in the article's Creative Commons licence, unless indicated otherwise in a credit line to the material. If material is not included in the article's Creative Commons licence and your intended use is not permitted by statutory regulation or exceeds the permitted use, you will need to obtain permission directly from the copyright holder. To view a copy of this licence, visit http://creativecommons.org/licenses/by/4.0/. The Creative Commons Public Domain Dedication waiver (http://creativeco mmons.org/publicdomain/zero/1.0/) applies to the data made available in this article, unless otherwise stated in a credit line to the data. 
need for the development of new drugs and drug delivery systems that are efficient, safe, and can be targeted to tumors.

Over recent years, numerous clinical trials and studies have demonstrated that extracellular vesicles (EVs) can serve as excellent drug carriers and have the potential to improve therapeutic effects against tumors [4]. They contain a large variety of genetic information and are widely present in blood, saliva, urine, tears, and cerebrospinal fluid, among other body fluids [5]. Additionally, because they are secreted by cells, EVs are biosafe, stable, and have good target specificity [6, 7]. They also have the advantages of deep tissue penetration and a surface structure that is similar to that of the cell membrane $[6,8]$, which allow them to act as carriers for the delivery of drugs to sites of disease [7]. Given their unique biological behavior, EVs have enormous potential for using in immunotherapy and precision treatment. With the advent of technologies that allow their modification, such as loading contents, EVs can now be modified to further improve their efficiency of drug delivery and target specificity, thus also enhancing therapeutic outcomes for tumor patients [9, 10]. However, the diversity of cell differentiation statuses and EVs composition has resulted in a lack of standardized isolation techniques and modification methods for EVs [11]. "Exosomes" are small membrane vesicles that contain a variety of substances and are a type of EVs [12]. However, only few studies have proven that the therapeutic EVs are exosomes, we refer to exosomes as "extracellular vesicles" throughout the review. Here, we focus on the isolation technologies of EVs, methods for their modification, and the therapeutic potential of EVs-based drug delivery systems.

\section{Biological properties}

EVs are rich in cholesterol, sphingomyelin, microRNAs (miRNAs), long non-coding RNAs (lncRNAs), a multitude of proteins that participate in intercellular communication $[13,14]$. Importantly, cargo carried by EVs can play key pathophysiological roles, including via intercellular communication and immunological responses $[13,15]$. EVs are nanoscale vesicles enveloped by cyto-membranes and can be broadly categorized into three types based on size: apoptotic vesicles, which are $>1000 \mathrm{~nm}$ in diameter [16]; microvesicles, which range from 100 to $1000 \mathrm{~nm}$ in diameter [17]; and exosomes, which have diameters that vary between 30 and $100 \mathrm{~nm}$ [18]. Moreover, EVs can be isolated and purified by using a variety of methods, including ultracentrifugation and chromatographic columns [19].

\section{EVs acquisition}

EVs can be broadly classified into three subtypes based on their origins: cell culture-derived EVs, bodily fluidderived EVs, and tissue-derived EVs [20]. Nevertheless, because EVs are secreted by cells into body fluids and tissues, cellular secretion represents the primary source of these vesicles.

For cell culture-derived EVs, the cell culture medium is a critical determinant of EVs yield as it supports cell proliferation and expansion. Three distinct types of medium are currently used to obtain cell culture-derived EVs: serum-containing medium, serum-free medium, and chemical composition substitution [21]. Notably, serum-free medium is frequently supplemented with components such as human platelet lysate (HPL) [22]. In general, serum-containing media are more conducive for cell growth and enhanced EVs production compared with serum-free media. HPL, fetal bovine serum (FBS), and human serum are frequently included in serum-containing media, and these media promote considerable cell proliferation [23, 24].

Importantly, when cells or products are employed for medicinal purposes, media containing animal components, such as FBS, should be avoided. Although information regarding serum concentrations in cell culture media is limited, higher serum concentrations are not always better, and should thus be kept within a tolerable range; however, this can vary according to the cell line used for EVs production [25]. Generally, serum-free media have less protein, which is detrimental to cell proliferation. Scaling up cell culture in such media typically requires supplementation with additives, cell growth components, and proper media adjustment procedures, known as chemical composition substitution [26]. Therefore, either medium with a complex chemical composition must be produced to allow for scale expansion, or the initial number of cells must be increased to critical levels in another medium before the cells are transferred to this serumfree medium for EVs production [21]. Additionally, studies have been reported on the effect of environmental conditions on the media, with oxygen content (reduced from the normal 21 to $2-7 \%$ ), shear stress, and stimulation with proinflammatory cytokines (IFN- $\gamma$ and TNF- $\alpha$ ) all reported to enhance the quality or quantity of secreted EVs [27, 28]. Environmental conditions are difficult to standardize for the industrial-scale production of EVs because EVs production varies by cell.

Compared with cell culture, body fluids contain mixtures of broader origin, such as serum proteins or mixtures of systemic EVs, which complicates their isolation [29]. Furthermore, the proportions of EVs in the circulatory system that are released from specific tissues are unknown [30]. Accordingly, cell culture is more 
frequently used to obtain EVs than bodily fluids. EVs in body fluids are increasingly being utilized for disease diagnosis and prognosis based on the surface protein profile of the EVs in each sample [31]. Research interest in the use of tissue-derived EVs (Ti-EVs) has markedly increased owing to several advantageous characteristics. Importantly, tissues contain vesicles released by most cell types in the tissue microenvironment and, thus, more precisely reflect pathological features [29]. Moreover, because Ti-EVs are produced from a single tissue, they have fewer impurities compared with bodily fluid-derived EVs [32]. However, other challenges, such as obtaining a therapeutic-scale yield, currently limit the use of Ti-EVs. Feasible solutions for this limitation include the reconstitution of 3D tissue-like structures (organoids), bioreactor-based culture methods, and treatment efficiency enhancement [20]. However, these technologies are still in their infancy, and require substantial research attention. Cell incubation remains the most frequently used approach for producing EVs on a large scale. However, there seems to be few devices have been developed for obtaining EVs through large-scale cell culture, a drawback that requires research attention.

\section{Techniques for EVs isolation}

Further assessment of EVs properties and uses requires the isolation of EVs of greater purity, i.e., cell debris and other interfering components must be removed. EVs secreted by different cells vary in size, function, and content, posing challenges to their extraction and isolation [33]. However, different EVs isolation and purification methods can be employed according to their characteristics [34, 35], including size, shape, density, and surface receptors (Table 1 ). The most common of these methods are ultracentrifugation, size-based isolation techniques, polymer precipitation techniques, immunoaffinity chromatography, and microfluidic-based isolation techniques.

\section{Centrifugation-based techniques}

Ultracentrifugation is considered the "gold standard" and is the most widely used technique for EVs isolation. The principle of ultracentrifugation is simple and mainly relies on differences in size, shape, and density of the components in the sample to obtain EVs under the appropriate centrifugal force [36]. The samples are subjected to multiple low-speed centrifugations to remove large biological particles, such as cell debris and apoptotic vesicles, and then centrifuged at high speed, following which the EVs contained in the supernatant are collected [36, 37]. This method is suitable for the isolation of samples with large sedimentation coefficients. Although this technique is widely used owing to its simplicity, it is time-consuming. Moreover, the centrifugal force and rotor type can affect
EVs purity, and the acquisition efficiency may not be sufficiently stable. Also, repeated centrifugation may result in EVs structural damage, thereby affecting their quality, which is not conducive to their subsequent analysis [37, 38]. This was shown in a study of supernatants obtained from non-small cell lung cancer cells (SK-MES-1), where EVs quality and recovery rate were reported to be reduced after repeating ultracentrifugation [39].

Density gradient centrifugation can yield EVs of higher purity compared with ultracentrifugation [40]. As the name implies, density gradient centrifugation separates the sample components based on differences in density, with greater differences indicating more effective isolation [41]. First, biological media of different densities (e.g., sucrose or glycerol iodide) are placed in a test tube, with the density of the media increasing sequentially from top to bottom. Next, the target sample is added to the top of the media and centrifuged with the appropriate force for the appropriate duration. Eventually, extracellular components are obtained in a layer with a specific density [42, 43]. Despite its simplicity and high-purity yield, this is a time-consuming and instrument-dependent method [44]. Additionally, EVs quality can be affected by the duration and force of centrifugation, which limits the large-scale application of this approach [37, 38].

\section{Size-based isolation techniques}

Size-based isolation techniques mainly refer to ultrafiltration and molecular exclusion chromatography, which are used to isolate EVs based on differences in size and molecular weight.

In the ultrafiltration technique, ultrafiltration membranes with different degrees of molecular weight retention are used to isolate EVs [45]. This method is suitable for the isolation of particles $<100 \mathrm{~nm}$ in diameter and can serve as an alternative to ultracentrifugation for EVs isolation owing to its higher isolation efficiency [46]. Furthermore, the employment of ultrafiltration membranes and columns with pore diameters of varying size allows for creating a population of particular dimensions, and plasma EVs of specific diameters have been obtained using such columns $[47,48]$. Notably, however, ultrafiltration is a time-consuming process, the pores in the ultrafiltration membrane are easily clogged, and the pressure applied during isolation may deform or rupture the EVs [49]. Sequential centrifugation has been proposed as a means of improving the ultrafiltration method. This involves the removal of impurities (e.g., cell debris) using a slightly larger pore size, followed by the depletion of free proteins, sample concentration, and, finally, EVs isolation using an ultrafiltration membrane with a specific pore size $[50,51]$. Sequential centrifugation has been 


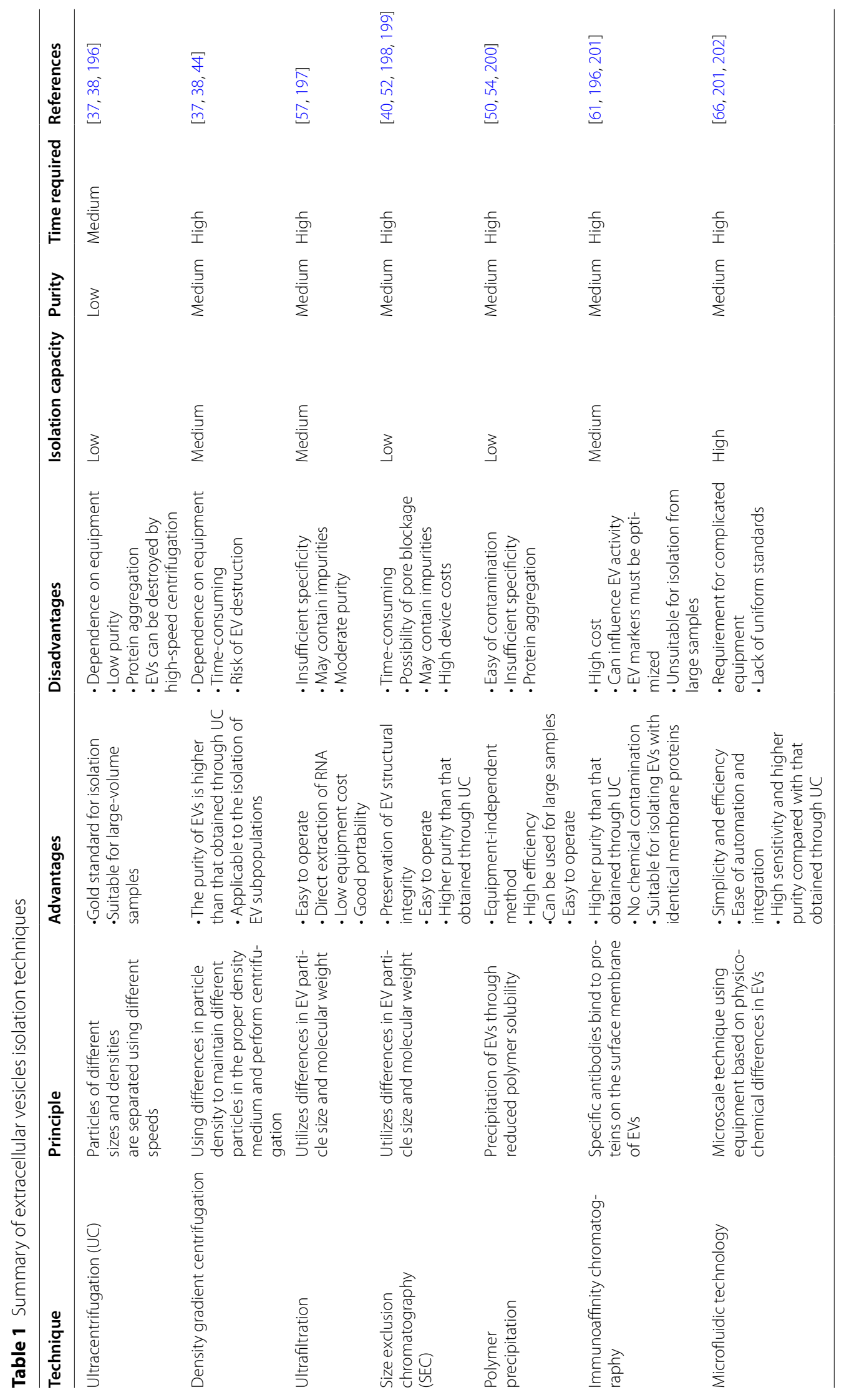


used to isolate EVs of high purity from human colon cancer cell lines [51].

The chromatographic method is based on the pore size of the stationary-phase gel of the isolation column. Sample components with higher molecular weight cannot enter the gel and are eluted early, while those with lower molecular weight (e.g., EVs) enter the pores and are eluted late [52]. This method is simple and retains the biological activity and structural integrity of EVs. Nevertheless, numerous disadvantages (e.g., the requirement for an isolation column, the laboriousness of the process, the column is easily contaminated by impurities, and the high cost) limit the application of this method $[40,52]$.

\section{Polymer precipitation}

Polymer precipitation is a commonly used technique for EVs isolation. Polyethylene glycol (PEG) interacts with water molecules near EVs to form a specific environment, which reduces the solubility of the EVs and causes them to precipitate [50]. The samples are pretreated to remove contaminants and subsequently co-cultured with PEG solution under suitable conditions for $24 \mathrm{~h}$ [53]. Finally, the precipitates are centrifuged to obtain EVs. The polymer precipitation method is simple, rapid, cost-effective, and not dependent on expensive equipment, meaning that it can be utilized for the large-scale isolation of EVs. However, polymers can also precipitate proteins, nucleic acids, and lipids and result in EVs contamination [54], thereby reducing EVs isolation efficiency and affecting their analysis. Commercial kits that employ polymer precipitation techniques for the isolation of EVs are currently available. Nonetheless, with this method, protein and lipid precipitation can contaminate EVs samples. Additionally, the high cost of polymer precipitation processes limits their applicability.

\section{Immunoaffinity chromatography}

Numerous specific membrane proteins are present on the EVs membrane surface, including CD63, HSP20, and chaperonin containing TCP1 subunit 2 (CCT2) $[55,56]$. These surface proteins can be used as specific molecular markers for EVs isolation. Immunoaffinity chromatography is used for the isolation and purification of EVs through specific antibody/ligand binding [57]. The isolation efficiency is closely related to protein affinity, matrix carriers, and elution conditions. This method can be used for the qualitative and quantitative analysis of EVs. According to the antibody substrate, this technique is mainly divided into the magnetic bead method, chromatographic fixation method, and enzyme-linked immunosorbent assay. Immunoaffinity chromatography offers the advantages of high specificity, high sensitivity, high EVs purity, and the maintenance of morphology
[58]. Quantitative assays have shown that, compared with ultracentrifugation, EVs purity can be enriched using this approach through the binding of the Vn96 peptide to EVs-resident heat shock proteins [59]. Because this technique uses EVs surface proteins for isolation, it can be used to isolate subpopulations of EVs produced by specific cells, thereby allowing for in-depth studies on their biological properties and functions. To date, immunoaffinity chromatography has been used to isolate EVs derived from $\mathrm{T}$ cells and melanoma cells. Using CD63 aptamers, Song et al. demonstrated that this technology might increase the efficiency of EVs isolation and lead to improved cancer diagnosis [60,61]. Additionally, the affinity of antibodies for their ligands enables them to access EVs-specific populations. Thus, specific EVs populations can be isolated using CD9-antibody-immobilized immunoaffinity and CD63 aptamer immunoaffinity [62].

This approach also has some disadvantages, including high cost, low yield, a requirement for strict storage conditions, and the susceptibility of EVs activity to changes in $\mathrm{pH}$ and salt concentrations [62, 63]. In addition, immunoaffinity chromatography is unsuitable for the isolation of EVs from large samples, and may also affect EVs purity through the adsorption of impure proteins, thereby limiting the applicability of this technique. Moreover, more stable and inexpensive antibody alternatives can be adopted to overcome the disadvantages of immunoaffinity chromatography, such as aptamer technology using RNA for the specific recognition of EVs [64]. The advantages of this technology are low variability, low cost, low immunogenicity, and ease of chemical modification. The stability of the technology depends on factors such as temperature, ionic strength, and buffer used [65].

\section{Microfluidics-based isolation techniques}

Microfluidics is an emerging technology used for the isolation of EVs from nanoparticles. Microfluidic-based methods can accurately and rapidly isolate EVs and improve enrichment efficiency [66, 67]. Consequently, they show promise for large-scale EVs isolation. Currently, the most widely used microfluidic techniques are primarily based on EVs particle size and immunoaffinity chromatography. Several devices have been developed for EVs isolation (e.g., acoustic, electrophoretic, and electromagnetic manipulation) [68-70]. A sonar filter is used to apply ultrasonic radiation to the sample particles. Because of differences in size and density among the particles, larger particles are subjected to stronger ultrasonic forces and thus migrate faster to the pressure node to complete EVs isolation [70]. Biocompatible polymers can also be added to the culture medium to control the viscoelasticity, yielding EVs of higher purity in the supernatant or serum [68]. In addition, microfluidic chips 
with an antibody coat have been used to efficiently isolate EVs from plasma [71]. Microfluidic technology provides excellent control of sample flow and mixing rate, rendering it an ideal tool for studying nanoparticles such as EVs [72]. Microfluidics can be used to isolate various EVs populations based on differences in particle size and immunoaffinity. This technique is analogous to the sizebased isolation and immunoaffinity chromatography procedures previously discussed. However, as microfluidic technology advances, more suitable procedures and devices for EVs isolation will likely be developed.

Owing to their role as transmitters of information between cells, EVs have promising potential as carriers of specific drugs and as a source of diagnostic and prognostic markers. The EVs subtypes have distinct modes of biogenesis, organelle sources, and compositional components. The comprehensive isolation and description of the spectrum of EVs subpopulations from a given source are required for a thorough understanding of their constituent molecules. Additionally, a high degree of purification of the vesicular populations is required to allow the characterization of the functional and therapeutic potential of EVs. Centrifugation is currently the most frequently used approach for EVs isolation. Nevertheless, techniques such as microfluidics and immunochromatography also show potential, but require optimization. Superior isolation procedures produce vesicles of high purity and consistent particle size and limit batch-to-batch variance among EVs subpopulations, which further facilitates EVs engineering and enhances the stability and scalability of therapeutic EVs. Additionally, the scalability of EVs production allows for increased drug transportation for targeted tumor therapy.

\section{Engineering modifications of EVs}

Because of their excellent properties, including biosafety, stability, and target specificity, EVs are considered to be good drug carriers for tumor therapy and represent a new generation of nanoscale drug delivery systems [6, 17]. However, the use of EVs for tumor therapy has several limitations, such as inefficient drug delivery and inadequate targeting ability. Over recent years, EVs have been specifically engineered to improve their tumor-targeting ability and drug delivery efficiency (Fig. 1).

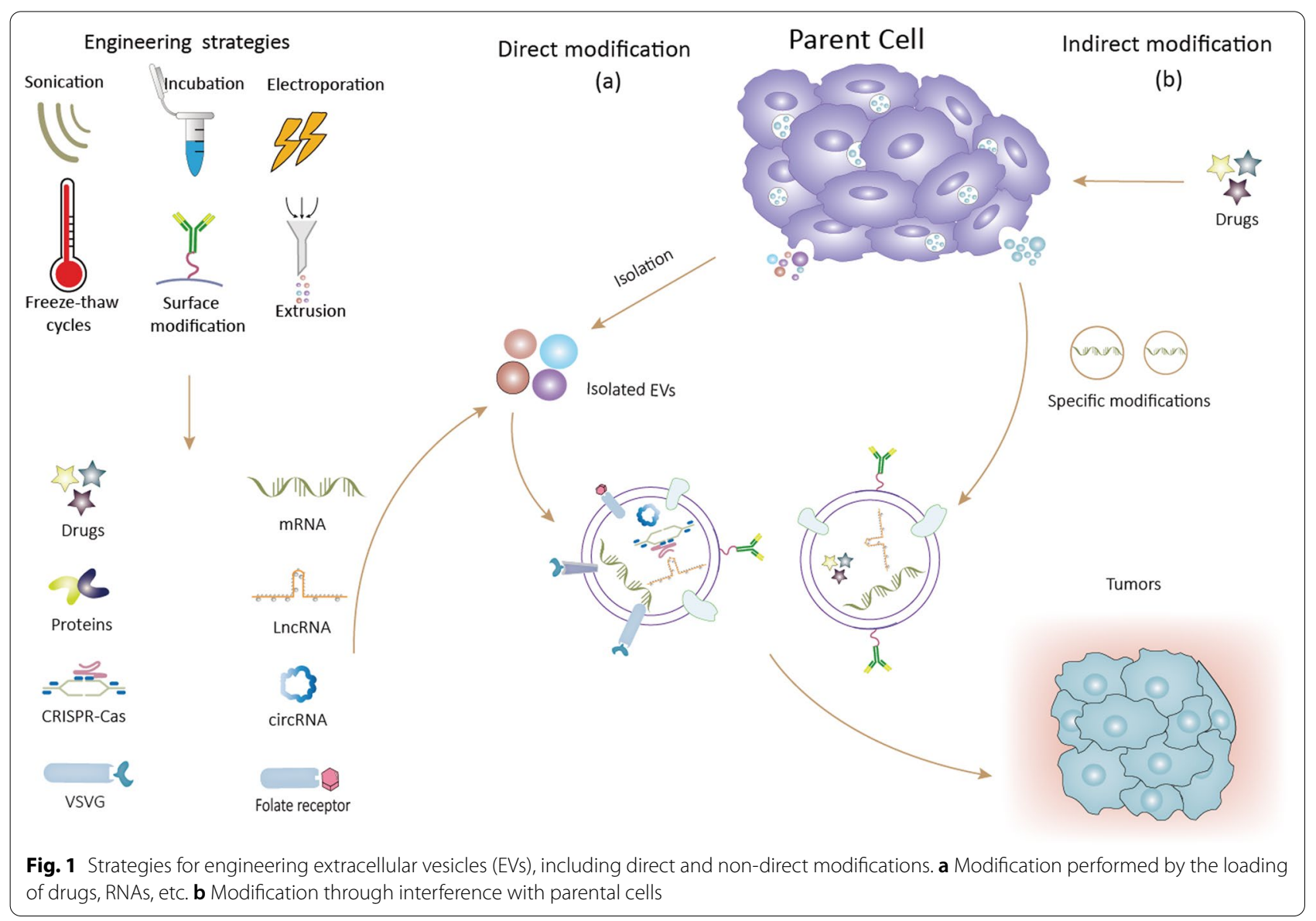




\section{Direct modifications}

Direct modification, also termed "EV engineering", the modification of surface proteins or contents of purified EVs using specific techniques under suitable conditions. This process is mainly divided into physical and chemical alterations.

\section{Physical modifications}

Owing to their structural characteristics, the surface and contents of EVs can be modified by physical means. The currently available methods include liposome membrane fusion and EVs content loading.

Surface modifications The traditional surface modification approach involves the expression of polypeptides or proteins on the EVs membrane using specific means. The sequences of peptides and targeted proteins have been inserted into EVs-associated membrane proteins to improve tumor targeting [73]. For instance, EVs containing imatinib have been fused to IL3 receptor to target chronic granulocytic leukemia and inhibit tumor growth [74]. Because EVs are enclosed in a lipid membrane, they can be fused with liposomes to form hybrid EVs [75]. Moreover, lipids with different compositions can affect the interactions between engineered EVs and cells. To obtain EVs with functional ligands, it is first neces- sary to prepare liposomes with the desired ligand and to complete the engineering of EVs through cell membrane fusion [76]. Liposomes were fused with mesenchymal stem cell-derived EVs to obtain a hybrid liposome system that was then loaded miR-34a. This system was shown to significantly enhance miRNA delivery efficiency and delay the progression of breast cancer [77].

Glycosylation is a stable EVs surface peptide modification that protects EVs surface proteins from hydrolytic degradation by proteases and can act to target EVs to specific tissues. Glycosyl phosphatidylinositol (GPI) is used for EVs surface modification and can serve as an anchor for functional ligands on the EVs surface [78]. GPI is suitable for the anchoring of a wide range of functional ligands, including proteins, antibodies, and RNA. Glycosylation is thought to improve EVs-based tumor therapy by enhancing targeted polymorphic effects [79]. Hong et al. engineered enzymatic vesicles expressing the native GPI-anchored form of interleukin-2 (IL-2) to improve tumor therapeutic efficiency through the targeting of the immunosuppressive and therapy-resistant tumor microenvironment (TME) [80].

Modifications of EVs contents Targeting and drug transport efficiency can also be improved by modifying EVs contents through other means (Table 2), such as elec-

Table 2 Direct physical modification of extracellular vesicles (EVs) (post-isolation and drug-loading modifications)

\begin{tabular}{|c|c|c|c|c|c|c|}
\hline $\begin{array}{l}\text { Modification } \\
\text { method }\end{array}$ & Advantages & Disadvantages & Drug delivered & $\begin{array}{l}\text { Drug delivery } \\
\text { efficiency }\end{array}$ & Application & References \\
\hline Simple incubation & $\begin{array}{l}\text { - Simplest operation } \\
\text {-Device-independent } \\
\text { method }\end{array}$ & $\begin{array}{l}\text { - Low loading effi- } \\
\text { ciency } \\
\text { - Time-consuming }\end{array}$ & $\begin{array}{l}\text { PTX, DOX, porphy- } \\
\text { rins, InCRNA }\end{array}$ & Approximately 15\% & $\begin{array}{l}\text { Loading EVs with } \\
\text { drugs }\end{array}$ & {$[83,203]$} \\
\hline Electroporation & $\begin{array}{l}\text { - Ability to load large } \\
\text { molecules } \\
\text { - Higher efficiency } \\
\text { compared with } \\
\text { simple incubation }\end{array}$ & $\begin{array}{l}\text { - Disruption of } \\
\text { EV integrity and } \\
\text { induction of siRNA } \\
\text { aggregation } \\
\text { - Device-independ- } \\
\text { ent method }\end{array}$ & $\begin{array}{l}\text { DOX, PTX, miRNA, } \\
\text { porphyrins }\end{array}$ & Approximately 20\% & $\begin{array}{l}\text { Drug loading and } \\
\text { targeting enhance- } \\
\text { ment }\end{array}$ & {$[204-206]$} \\
\hline Sonication & $\begin{array}{l}\text { - High efficiency } \\
\text { - Suitable for small } \\
\text { mRNA }\end{array}$ & $\begin{array}{l}\text { - Device-dependent } \\
\text { method } \\
\text { - Destruction of } \\
\text { the stability of EVs } \\
\text { membrane }\end{array}$ & $\begin{array}{l}\text { PTX, DOX, } \\
\text { miRNA, siRNA }\end{array}$ & Approximately 25\% & $\begin{array}{l}\text { Improvement of } \\
\text { drug loading effi- } \\
\text { ciency }\end{array}$ & {$[91,92,207]$} \\
\hline Extrusion & $\begin{array}{l}\text { - Easy of operation } \\
\text { - High efficiency } \\
\text { - Short duration }\end{array}$ & $\begin{array}{l}\text { - Device-dependent } \\
\text { process } \\
\text { - Disruption of the EV } \\
\text { membrane }\end{array}$ & Catalase, DOX & Approximately 23\% & $\begin{array}{l}\text { Improvement of } \\
\text { drug delivery effi- } \\
\text { ciency and activity } \\
\text { against tumor tissue }\end{array}$ & {$[83,92]$} \\
\hline Freeze-thaw & $\begin{array}{l}\text { - No change in EV } \\
\text { surface charge }\end{array}$ & $\begin{array}{l}\text { - Low loading effi- } \\
\text { ciency owing to EV } \\
\text { aggregation }\end{array}$ & Porphyrins, PTX & $\begin{array}{l}\text { High drug delivery } \\
\text { capacity }\end{array}$ & $\begin{array}{l}\text { The targeting of } \\
\text { tumors with loaded } \\
\text { drugs }\end{array}$ & [94-96] \\
\hline Saponin & $\begin{array}{l}\text { - Higher loading } \\
\text { efficiency compared } \\
\text { with simple incuba- } \\
\text { tion }\end{array}$ & $\begin{array}{l}\text { - Possible membrane } \\
\text { degeneration } \\
\text { - In vivo toxicity }\end{array}$ & DOX, porphyrins & Approximately 15\% & $\begin{array}{l}\text { Loading EVs with } \\
\text { drugs and enhanc- } \\
\text { ing antitumor effects }\end{array}$ & {$[96,208]$} \\
\hline
\end{tabular}


troporation. The established content modification process involves the loading of EVs with chemotherapeutic drugs, proteins, miRNAs, and lncRNAs.

Simple incubation The co-incubation of EVs with drugs at room temperature is a commonly used method for drug loading. Although this approach is simple, it is inefficient mainly because the EVs volume and small membrane pore size limit drug entry [81]. The clustered regularly interspaced short palindromic repeats (CRISPR)/CRISPR-associated protein (CRISPR-Cas) system can be delivered to EVs secreted by mesenchymal stem cells (MSCs) through a simple liposome/EVs incubation process [82]. However, the loading of EVs with drugs through simple incubation is inefficient when compared with electroporation, extrusion, and sonication [83].

Electroporation The EVs surface has numerous porous channels and charge. Hence, incubation with drugs and the application of an electric current can be used to instantly improve the permeability of the EVs membrane, allowing for rapid drug entry [84, 85]. Nonetheless, electroporation can induce vesicle or siRNA aggregation, thereby damaging the structure of engineered EVs or reducing the therapeutic effect of loaded drugs [86]. To overcome this challenge, trehalose pulse medium or chelating agents such as ethylenediaminetetraacetic acid can be added to the reaction [87]. Furthermore, one study reported that, for the loading of miRNA-155 into EVs by electroporation, the best loading efficiency was achieved at a voltage of $0.13-0.2 \mathrm{kV}$ and an EVs concentration of $500-1000 \mathrm{mg} / \mathrm{mL}$ [88].

Sonication In sonication, an ultrasound probe with different amplitudes is used to permeabilize the EVs membrane and promote drug loading [89]. Sonication resulted in better drug loading efficiency and slower release compared with other physical methods such as simple incubation and electroporation [83]. Moreover, sonicated EVs display better biocompatibility and targeting effects. However, ultrasound radiation promotes the aggregation of EVs surface proteins and affects the physicochemical properties of the EVs membrane. Notably, sonication destabilizes the structure of EVs to a greater extent than other physical methods [90]. The loading of paclitaxel (PTX) into macrophage-derived EVs through sonication led to a $>50$-fold increase in the cytotoxicity of the drug, resulting in significant inhibition of tumor tissue growth in vivo [91].

Extrusion In this method, an extruder is used to squeeze the cells co-cultured with the drug to complete drug loading. This approach results in uniformly sized EVs and more efficient drug loading compared with simple incubation [92]. For instance, EVs mimics were obtained by multiple sequential extrusion of MCF10A cells, and subsequently encapsulated with siRNA. The drug-loading efficiency of EVs mimics was reported to be higher than that obtained with natural EVs [93]. Importantly, mechanical extrusion can affect EVs membrane integrity, indicating that extrusion conditions and environment should be taken into consideration when this method is employed for EVs loading [89].

Freeze-thaw cycles Freeze-thawing involves the formation of temporary pores on the EVs membrane through multiple rapid freeze-thaw cycles to allow drug entry [94]. Freeze-thawing can be applied in the mass production of EVs; however, the associated loading efficiency is lower than that observed with ultrasonication [91]. Repeated freeze-thaw cycles can lead to an increase in EVs particle size and may improve drug loading efficiency [95].

Saponin Saponins are surfactant molecules that, when incubated with EVs, form pores in their membranes through interaction with cholesterol. This process increases membrane permeability, thereby improving drug loading. After drug loading, the EVs are purified by membrane dialysis and chromatography [96]. This method allows gentle drug loading into EVs without disrupting the integrity of the membrane surface, resulting in high loading efficiency and stable drug release [83]. Saponin-mediated permeabilization has been used to load hydrophilic porphyrin, leading to an 11-fold higher efficiency of drug loading into breast cancer cell-derived EVs relative to the passive loading method [96].

Virus loading The loading of EVs with specific drugs can be achieved using viruses. This approach can increase the efficiency of transport of certain cargos by EVs, such as RNA and proteins [97-99]. One study demonstrated that infection with Zika virus resulted in more efficient RNA and protein packaging, as well as a better transport rate, in neuronal cell-derived EVs [99]. Furthermore, "engineered EVs" formed by the fusion of the MS2 phage shell protein with EVs-associated proteins led to a six-fold increase in RNA loading efficiency [98].

\section{Chemical modifications}

Chemical modification mainly involves the transformation of the EVs surface and can be categorized as covalent and non-covalent (Table 3). Covalent modifications can be accomplished by chemical reactions involving EVs and specific molecules or chemical linkers. Notably, noncovalent modifications can be accomplished by electrostatic interactions and lipid fusion under suitably mild conditions.

Covalent modifications Covalent modifications mainly include chemical conjugation, which is the direct attachment of ligands to the EVs surface through click chem- 


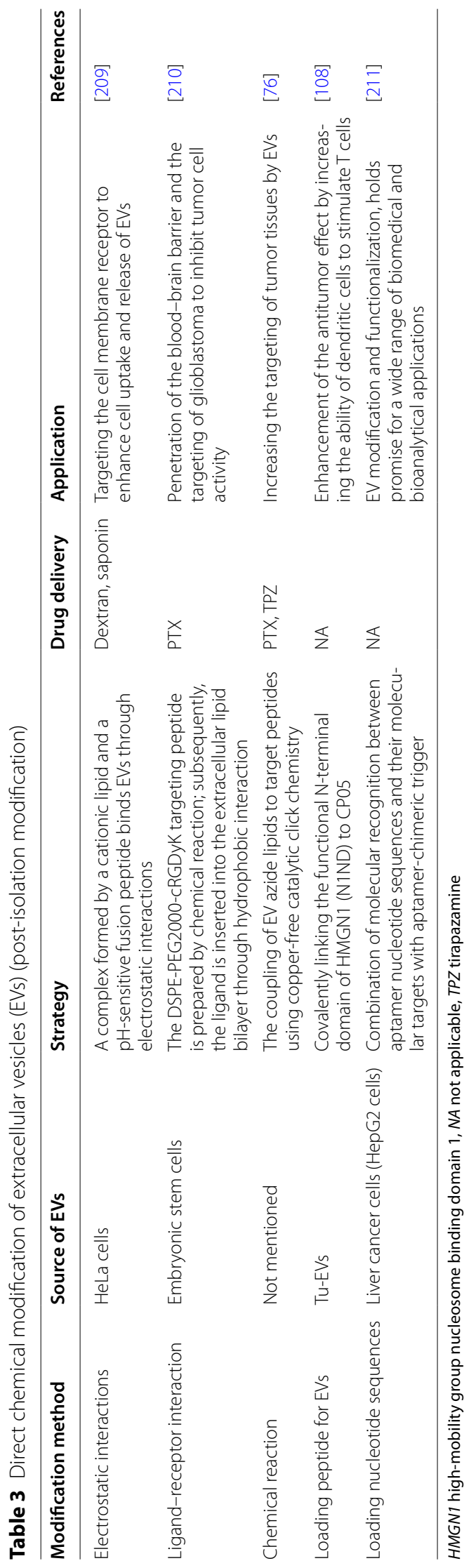


istry. The numerous amino groups on the EVs surface can be used as targets for simple molecules such as fluorescent dyes and PEGs [100]. The surface modification of EVs through the azide-alkyne cycloaddition reaction has been achieved, resulting in the conjugation of azide-fluor 545 to EVs chemically modified with alkyne groups [101]. In addition, strain-promoted alkyne-azide cycloaddition between dibenzocyclooctyne and azidelabeled cRGD peptide on the surface of EVs can be targeted to treat ischemic injury in the mouse brain [102]. Chemical conjugation is characterized by speed of reaction, high selectivity, and compatibility. Furthermore, this method does not affect the structural integrity of EVs. However, conditions (e.g., temperature, pressure, and osmotic pressure) must be carefully controlled during the modification process to avoid EVs rupture and denaturation [103].

Non-covalent modifications The genetic engineering of EVs-producing cells and click chemistry are both widely used for EVs surface modification. Certain non-covalent modification techniques are also under investigation for the production of targeted EVs, such as electrostatic and ligand-receptor interactions.

Electrostatic interactions The EVs surface is negatively charged with a zeta potential of approximately $-8.82 \mathrm{mV}$. This can be used to equip the EVs with cations, which is achieved by the binding of highvalent cations to the negatively charged EVs surface [104]. Accordingly, an EVs-based immunoblocker was designed to enhance the phagocytosis of tumor cells by macrophages through antagonism of the interaction between CD47 and SIRP $\alpha[105,106]$. However, some cationic materials may be cytotoxic and can cause lysosome degradation and reduce EVs purity when they enter the cell [107].

Ligand-receptor interactions This method uses hydrophobic ligands or lipid ligands for automatic insertion onto the EVs surface through hydrophobic interaction. PEG-modified liposome derivatives are commonly mixed with EVs and incubated at specific temperatures to automatically insert the liposomes onto the EVs surface. The modification of EVs derived from mouse neuroblastoma cells with PEG significantly prolonged the EVs circulation time in blood and improved the targeting of EVs.

Others Certain peptides and nucleotide sequences can be loaded onto the EVs surface through specific approaches. For example, the CP05 peptide was loaded into EVs after binding to N1ND. This process enhanced the ability of dendritic cells (DC) to stimulate $\mathrm{T}$ cells for tumor immunotherapy [108].

\section{Indirect modification}

Although most cells can produce EVs, those released by parental cells can differ depending on the culture conditions [109]. Therefore, incubating parental cells under the appropriate conditions allows for the generation of specific EVs types. The parental cells of EVs can be genetically and metabolically engineered to enhance the tumor-targeting capabilities and drug delivery efficiency of the derived EVs (Table 4).

\section{Genetic engineering}

Genetic engineering for the modification of parental cells to achieve improved targeting and a greater number of drug-loaded EVs is becoming increasingly sophisticated. Membrane proteins on the surface of EVs can bind to target ligands. Accordingly, a plasmid vector encoding the membrane protein Lamp2b fused to the rabies viral glycoprotein (RVG) was transfected into parental cells. Subsequently, parental cells produced EVs expressing the Lamp2b/RVG fusion as a targeting peptide on the EVs surface [110]. Lamp2 is the commonly used targeting membrane protein. For example, the cardiac-targeting peptide/Lamp2b fusion protein was transfected into HEK293 cells to obtain EVs that could target the heart [111]. Alternatively, DCs were transfected with a Lamp2b-modified pEGFP-C1 vector to generate RVGengineered EVs [112]. However, the genetic modification of EVs parental cells faces numerous difficulties, as the introduced surface-targeting ligands may affect the normal function of EVs membranes and introduce foreign impurities, resulting in lower EVs purity. This underlines the need for improved genetic engineering techniques for targeting parental cells.

\section{Metabolic engineering}

Besides genetic engineering, metabolic engineering can also be used to modify EVs parental cells by adding specific substances, such as amino acids, lipids, and polysaccharides, to the parental cell growth medium to promote cellular biosynthesis. After uptake, these substances are integrated into the proteome, glycoproteins, and liposomes contained by the EVs [109]. The metabolic labeling of newly synthesized proteins or glycan/glycoproteins of EVs-secreting cells has been combined with chemically active azide groups and bio-orthogonal click conjugation to modify and functionalize EVs [113].

\section{Loading of exogenous substances}

Modifications can also be accomplished by adding contents to parental cells through specific means. Tumortargeted EVs loaded with miR-199a were obtained by the transfection of a specific binding transcriptional activator 


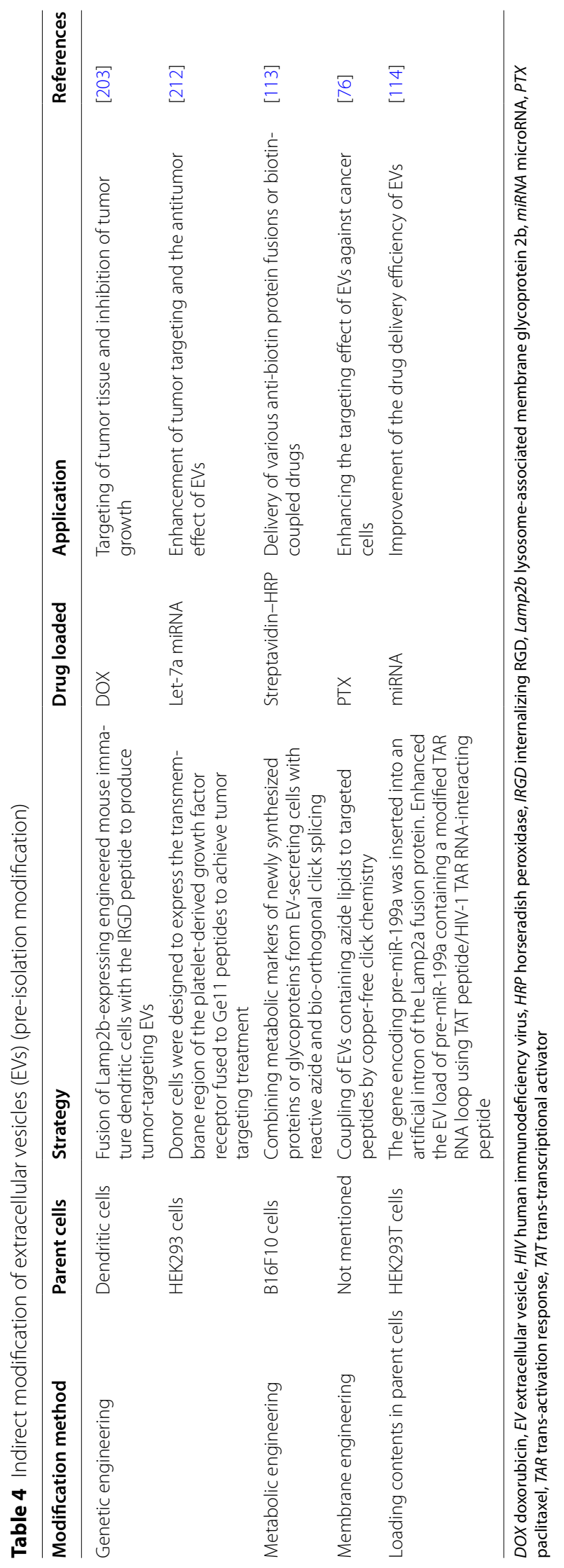


fused to Lamp2a into HEK293 cells, followed by incubation under suitable conditions [114].

\section{EVs engineering techniques: conclusions}

EVs engineering can improve EVs tumor targeting ability and drug loading efficiency. For instance, azidemodified EVs generated from M1 macrophages were coupled with dibenzocyclooctyne-modified CD47 and SIRP $\alpha$ antibodies (aCD47 and aSIRP $\alpha$ ). This modified EVs actively targeted tumors and blocked SIRP $\alpha$ and CD47 on macrophages, eliminating the "don't eat me" signal and improving macrophage phagocytosis [106]. However, complicated engineering processes restrict the therapeutic deployment of manufactured EVs on a wide scale, highlighting the need for the development of a simple and effective means of engineering EVs for improved tumor therapy. As an example, the development of electroporation and ultrasound devices, which are now widely used, has improved the efficiency of encapsulation of antitumor drugs.

\section{EVs storage}

EVs stability varies under different storage conditions, such as different temperatures. EVs are usually stored at $4,-20$, or $-80{ }^{\circ} \mathrm{C}$. Furthermore, protease inhibitors and alginose are added to the storage medium to safeguard the integrity of the EVs membrane $[115,116]$. The protein content on the surface of EVs is highest when EVs are stored at $4{ }^{\circ} \mathrm{C}$ for a short time $(24-48 \mathrm{~h})$, while stability is greatest when they are stored at $-80{ }^{\circ} \mathrm{C}$ for a long time ( $>1$ week) [117]. Hence, the objectives of a given study and the storage period determine the best storage conditions for EVs. For short-term storage, isolated EVs can be maintained at $4{ }^{\circ} \mathrm{C}$ for days or weeks [116]. For months of storage, isolated EVs should be stored at $-80^{\circ} \mathrm{C}$. Furthermore, freezing and thawing cycles can significantly affect EVs durability. Studies have suggested that EVs are structurally susceptible to repeated freeze-thaw cycles owing to the vulnerability of their phosphatidylserine moieties [118]. Consequently, multiple freezing and thawing cycles should be avoided when storing EVs as this may greatly impair EVs integrity and stability [116].

\section{Tumor targeting with EVs}

EVs may be utilized to address the poor tumor-targeting ability of traditional chemotherapeutic drugs. For instance, MSCs have homing capacity, that is, under the action of a variety of factors, they can cross vascular endothelial barriers to reach and colonize target tissues [119]. Furthermore, following ischemia, hypoxia, or injury, MSC-derived EVs (MSC-EVs) can migrate to sites of inflammation as well as to tumor tissues. This homing property of MSCs has been used to target MSC-EVs to tumor tissue and improve the efficiency of targeted tumor therapy. For example, the ability of MSC-EVs to target 5-fluorocytosine and mRNA to tumor tissues has been investigated for the development of new targeted therapies [120]. EVs secreted by tumor cells (Tu-EVs) may be able to act on tumor tissues. Their surface is decorated with parent cell-derived signaling molecules and their intravesicular content, including DNA, mRNA, miRNA, enzymes, and soluble factors, are all biologically active and capable of executing functional responses in target cells and retargeting to maternal tumor cells [121]. Tu-EVs carrying the chemotherapeutic drug doxorubicin can preferentially fuse with maternal cancer cells, thereby prolonging the retention time of the drug in the tumor [122]. This demonstrates the homing properties of $\mathrm{Tu}$-EVs and provides a new direction for targeted tumor therapy. Additionally, biocompatible tumor-cell-exocytosed EVs-biomimetic porous silicon nanoparticles have been developed as drug carriers for targeted chemotherapy [123]. Therefore, the use of Tu-EVs offers promise for the targeted treatment of cancer.

The folate receptor (FR) is a glycoprotein present on the surface of cell membranes and is anchored to the cell membrane by GPI. It has a very high affinity for folate and is used for specific binding. FR is highly expressed in tumor cells, especially those of epithelial origin (e.g., pancreatic cancer) [124]. Thus, FR can be used to target tumors, while folate can be employed as a target for the preparation of FR-mediated tumor cell-targeted EVs (Co-EVs-FA) to increase the delivery of tumor-targeting drugs. For example, EVs-PH20-FA obtained by assembling folate into EVs through genetic engineering technology were shown to be able to target tumor tissue to enhance drug delivery [125].

Hyaluronic acid (HA), a glycosaminoglycan and a major component of the extracellular matrix, is highly expressed in several solid malignancies [126]. Hyaluronidases (HYALs) are endo- $\beta$ - $\mathrm{N}$-acetylglucosaminidases that degrade HA via hydrolysis of the $\beta(1,4)$-glycosidic bond between $\mathrm{D}$-glucuronic acid and N-acetyl-D-glucosamine [127]. Therefore, mutual HYAL/HA recognition can be used to develop new strategies for tumor-targeting therapy. HA is highly concentrated in pancreatic ductal adenocarcinoma and is associated with a poor prognosis. The PEGylated form of recombinant human hyaluronidase PH-20 (PEGPH20) was used in pancreatic ductal adenocarcinoma alongside cytotoxic agents to enhance tumor targeting and the efficiency of drug delivery by recognizing HA around the tumor stroma [128].

Numerous other substances similar to FRs and HYALs, such as matrix metalloproteinases (MMPs), can be used in tumor-targeted therapy. Zhang et al. loaded MMP substrate peptide into multifunctional mesoporous $\mathrm{SiO}_{2}$ 
nanoparticles to selectively target MMP-rich hepatocellular carcinoma (HCC) cells and subsequently induce the intracellular release of a cytotoxic drug [129].

\section{Engineered EVs in tumor therapy}

As drug carriers and delivery vehicles, EVs offer the following advantages: (1) Biological stability and the ability for long-term storage while maintaining their activity, thereby simplifying storage and transport; (2) low immunogenicity, which avoids activation of the immune response; (3) good biocompatibility, with almost no elimination by the immune system; and (4) a lack of differentiation ability, which prevents abnormal differentiation and tumor transformation [130-132]. Because EVs have a lipid bilayer membrane structure, their internal cavity can store water-soluble drugs, while the hydrophobic region in the lipid bilayer can receive hydrophobic drugs. This protects the contents from the effects of the harsh TME, thus preventing the decomposition of the drug before it reaches the tumor, as well as ensuring drug efficacy and the avoidance of toxicity [4]. In solid tumors, EVs have demonstrated enhanced permeability and a retention effect, resulting in targeted aggregation. The special membrane structure of EVs allows their direct fusion with the cell membrane and the transfer of the loaded drug into target cells, avoiding the problems of drug release and cytotoxicity associated with the phagocytosis-lysosome pathway [123]. These characteristics make EVs an ideal delivery system (Table 5).

\section{EVs loaded with different drugs for tumor therapy}

Although chemotherapy is the mainstay of cancer treatment, side effects have limited its application. However, research into the targeting ability and delivery efficiency of EVs may provide a reference for improving their antitumor effect and mitigating the side effects associated with chemotherapy. Based on the excellent properties of EVs, multiple drugs have been loaded into EVs for tumor therapy, including chemotherapeutic drugs, RNAs, proteins, and even viruses.

PTX, which induces mitotic arrest, is used for the treatment of a variety of tumors [133]. Cancer cell-derived EVs loaded with PTX demonstrated enhanced prostate cancer targeting and cytotoxicity toward tumor cells [134]. Additionally, doxorubicin-loaded EVs were encapsulated with A33 antibody (A33Ab-US-EVs/Dox), which increased the ability of the EVs to target doxorubicin to colon cancer cells when compared with that for free doxorubicin, thereby extending survival in mice [135]. DNA replication, an essential process for tumor cell growth, can be disrupted by apolipoprotein-containing fibroblast-derived EVs loaded with methotrexate, which show excellent glioma targeting and killing effects [136]. Similarly, other chemotherapeutic agents, such as gemcitabine and cisplatin, have also been loaded into EVs for

Table 5 Therapeutic antitumor effects of various engineered extracellular vehicles (EVs)

\begin{tabular}{|c|c|c|c|c|c|}
\hline Source of EVs & EV cargos & Loading approach & Type of cancer & Function & References \\
\hline HEK293T cells & SiRNA & Membrane-anchoring & Prostate cancer & $\begin{array}{l}\text { Enhanced EV tumor } \\
\text { targeting and inhibition of } \\
\text { prostate cancer growth }\end{array}$ & {$[213]$} \\
\hline HepG2 cells & miR-31 and miR-451 & Electroporation & Hepatocellular carcinoma & $\begin{array}{l}\text { Inhibition of tumor cell } \\
\text { proliferation and migra- } \\
\text { tion }\end{array}$ & {$[214]$} \\
\hline Panc02 cells & $\begin{array}{l}\text { Nanoscale metabolic } \\
\text { precursors }\end{array}$ & Click chemistry & Pancreatic cancer & $\begin{array}{l}\text { Improving the tumor tar- } \\
\text { geting of EV drug delivery } \\
\text { systems }\end{array}$ & {$[215]$} \\
\hline LNCaP PC -3 cells & PTX & Incubation & Prostate cancer & $\begin{array}{l}\text { Improving chemo- } \\
\text { therapeutic drug delivery } \\
\text { efficiency and enhancing } \\
\text { cytotoxic effects }\end{array}$ & {$[134]$} \\
\hline Macrophage cells & DOX, PTX & $\begin{array}{l}\text { Electroporation/sonica- } \\
\text { tion }\end{array}$ & Lung cancer & $\begin{array}{l}\text { Improving chemotherapy } \\
\text { drug delivery efficiency to } \\
\text { inhibit tumor growth }\end{array}$ & [91] \\
\hline Mesenchymal stem cells & PLK-1 siRNA & Electroporation & Bladder cancer & $\begin{array}{l}\text { Improving the targeting } \\
\text { of EVs to tumor cells }\end{array}$ & [216] \\
\hline Ovarian cancer & DOX & Electroporation & Ovarian cancer & $\begin{array}{l}\text { Improving chemotherapy } \\
\text { drug delivery efficiency to } \\
\text { inhibit tumor growth }\end{array}$ & {$[217]$} \\
\hline Red blood cells & Cas9 mRNA & $\begin{array}{l}\text { Electroporation/incuba- } \\
\text { tion }\end{array}$ & Breast cancer & $\begin{array}{l}\text { Improving the targeting } \\
\text { of EVs to tumor cells and } \\
\text { reducing adverse effects }\end{array}$ & {$[144]$} \\
\hline
\end{tabular}


tumor-targeted therapy, and have demonstrated good effects [137].

RNAs can interfere with normal tumor metabolism by silencing gene expression in a sequence-specific manner. Thus, RNA-loaded EVs may provide options for tumor therapy. Mutations in the KRAS gene, which encodes a GTPase, are key drivers of pancreatic cancer [138]. SiRNAs that target oncogenic KRAS ${ }^{\mathrm{G} 12 \mathrm{D}}$ were loaded into normal fibroblast-derived EVs by electroporation, and these engineered EVs targeted pancreatic cancer tissue and inhibited tumor-cell growth [139]. Resistance to chemotherapeutic drugs is an ongoing challenge in tumor treatment. Recently, it was found that miRNAs can be used to modify the drug resistance phenotype of tumor cells. An in vitro assay showed that EVs derived from human gastric epithelial cells could deliver antimiR-214, resulting in the reversal of chemoresistance to cisplatin in gastric cancer cells [140]. Genetic engineering is an emerging therapeutic modality for tumors. MiRNAs have been shown to regulate tumor cell migration, invasion, and pre-metastatic niche formation through the transcriptional repression of target genes. For instance, ovarian cancer cell-derived EVs loaded with miR-199a-3p could downregulate the expression of the miR-199a-3p target gene mesenchymal-epithelial transforming factor (c-Met), which inhibited tumor cell proliferation and invasion [141]. Engineered EVs were used to deliver the antitumor drug fluorouracil (5-FU) and miR-21 inhibitor oligonucleotides to colon cancer cells expressing human epidermal growth factor receptor-2 (HER2), which reversed the resistance of the cancer cells to 5 -FU and enhanced antitumor cytotoxicity [142]. These studies highlight the potential of RNA-loaded EVs for engineering applications in the treatment of cancer.

The CRISPR/Cas 9 system, widely used as a genome editing tool, holds excellent promise in biomedicine, especially for drug delivery in oncology. In one study, ovarian cancer-derived EVs were loaded with plasmids expressing CRISPR/Cas9 targeting poly (ADPribose) polymerase-1 (PARP-1) to treat ovarian cancer. This engineered EVs system synergized with cisplatin to induce apoptosis in ovarian cancer cells [143]. Similarly, red blood cell-derived EVs were loaded with Cas9 mRNA targeting miR-125b, which enabled gene editing and, consequently, the inhibition of leukemia cell growth through the suppression of miR-125b expression [144].

The emergence of viral therapies may offer new options for oncological therapy. Oncolytic viruses can be engineered to selectively infect tumor cells without affecting normal tissue. They replicate in the cancer cells and eventually cause their death [145]. In a lung cancerrelated study, oncolytic viruses and PTX were encapsulated in lung cancer cell-derived EVs, which were then administered intravenously for tumor treatment. This engineered EVs system demonstrated stronger tumor growth inhibitory activity compared with free PTX [146]. Collectively, these different agents provide new paradigms for EVs-based oncological therapy.

\section{EVs from different cells used in tumor therapy}

Due to the multiple substances carried by EVs, MSCsEVs can play an important role in cell proliferation and immune regulation and affect tumor progression by regulating the TME [147]. Although the conventional view holds that MSC-EVs can promote tumor growth and metastasis [148], many studies have suggested that some MSC-EVs can exert the opposite effects. Furthermore, mounting evidence indicates that MSC-EVs also have strong therapeutic potential, e.g., for repairing tissue, eliminating inflammation, regulating immunity, and suppressing tumors [149]. Importantly, MSCs have a strong capacity for EVs production and MSC-EVs have tumor-homing ability [119]. Based on these characteristics, MSC-EVs show great promise as tools for tumortargeting therapy. Numerous studies have shown that MSC-EVs loaded with antitumor drugs can specifically target tumor tissues [150], resulting in stronger antitumor effects and fewer side effects. For instance, EVs derived from bone marrow MSCs (BM-MSC-EVs) loaded with doxorubicin were reported to improve the efficiency of drug uptake and antitumor effects in MG63 osteosarcoma cells [151]. Similarly, modified MSC-EVs expressing miRNA-199a, which targets AGAP2, were delivered to glioma cells, resulting in the inhibition of glioma development [152]. Immune escape is a key factor in tumor growth and invasion. Some MSC-EVs can inhibit tumor progression by suppressing immune escape in the TME, and generating drug delivery systems using this mechanism may further improve the efficiency of tumor therapy. For example, EVs from adipose tissue-derived MSCs (AD-MSCs) modified to express miRNA-424 can delay the progression of triple-negative breast cancer by blocking programmed cell death protein 1/programmed cell death 1 ligand 1 (PD-1/PD-L1) [153]. Furthermore, the loading of siRNA and oxaliplatin into BM-MSCs-EVs by electroporation can enhance the antitumor effect of oxaliplatin in pancreatic ductal adenocarcinoma [154]. This could be achieved by increasing the recruitment of $\mathrm{T}$ lymphocytes and downregulating that of regulatory $\mathrm{T}$ cells (Tregs), thereby suppressing immune escape. We suggest that using the MSC-EVs-based drug delivery system with tumor-suppressive capacity may represent a feasible strategy for tumor immunotherapy (Fig. 2).

EVs secreted by tumor cells are involved in a variety of cellular functions and pathological events in the TME. Tu-EVs carry a variety of miRNAs and mRNAs that can 


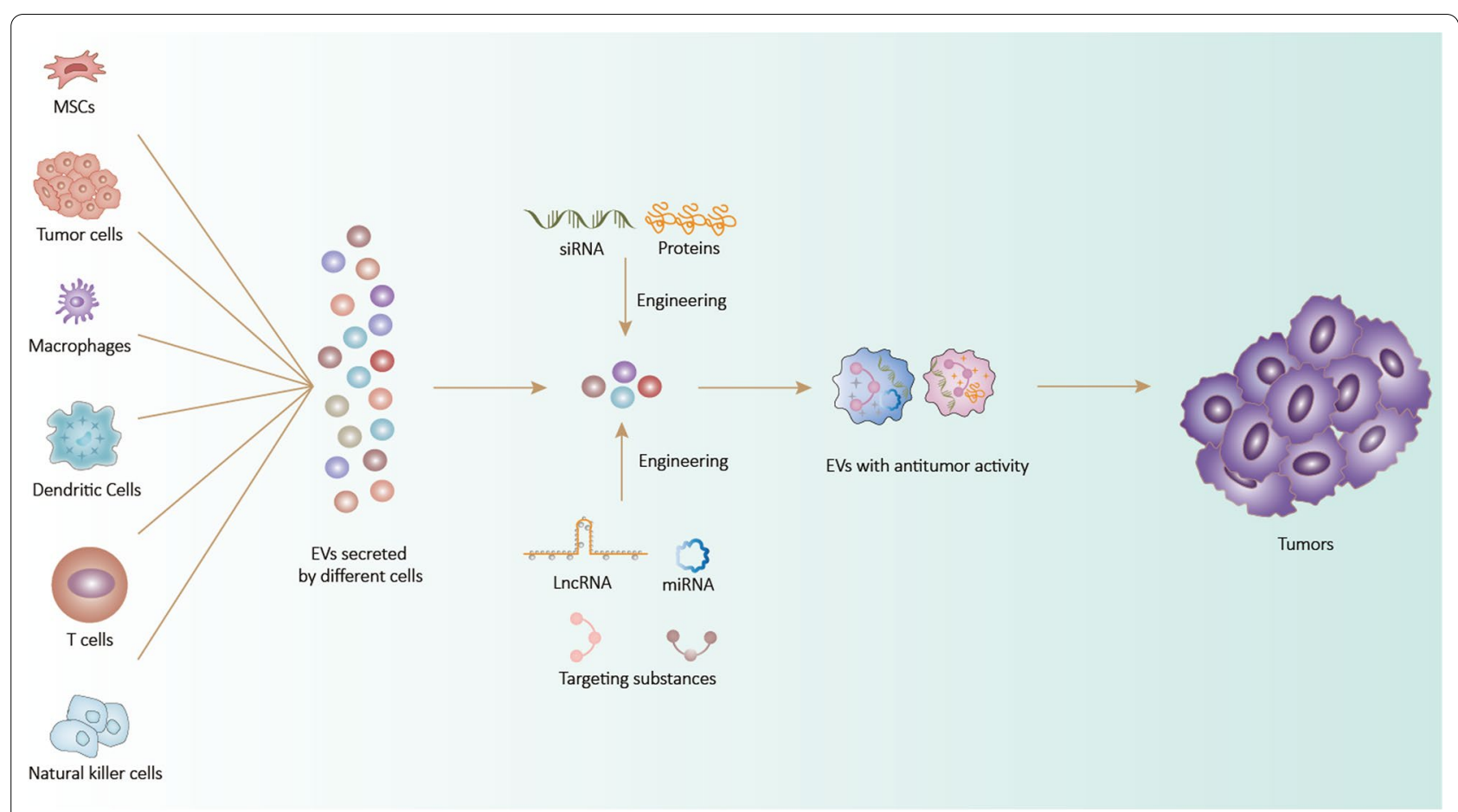

Fig. 2 After being engineered, extracellular vesicles (EVs) secreted by different cells exert therapeutic effects on tumors

be transferred to recipient cells, with the latter being translated into functional proteins [155]. Accordingly, Tu-EVs can support cancer transformation by delivering oncogenic signals to target cells, thus maintaining the autocrine growth-promoting pathway in parental tumor cells and altering stromal cell function in the TME [156]. Importantly, because Tu-EVs carry the same cytokines or chemokines as parental cells, signal delivery occurs preferentially between parental tumor cells [157]. Hence, Tu-EVs can be used as drug carriers in oncology owing to their excellent targeting capability with respect to parental cells. For instance, breast cancer cellderived EVs loaded with doxorubicin can target breast cancer cells and inhibit tumor invasion by suppressing tumor angiogenesis [158]. Moreover, EVs derived from B16 melanoma cells transfected with a plasmid encoding the Mycobacterium tuberculosis antigen early secretory antigenic target-6 (ESAT-6) were found to be able to significantly inhibit tumor growth in syngeneic B16 tumor-bearing mice [159]. These observations highlight the great potential of Tu-EVs as a drug carrier; however, future research should focus on how to avoid events where substances carried by Tu-EVs can promote tumor progression.

EVs derived from immune cells can target tumor cells, thus mimicking the parent cell, and exhibit drug-carrying capacity. In recent years, EVs secreted by macrophages
(M-EVs) have been modified for tumor therapy, with promising results. The loading of PTX into M-EVs by ultrasonication led to a 50-fold enhancement of the cytotoxic effect of PTX on drug-resistant tumor cells [91]. Similarly, Li et al. modified M-EVs with a peptide to target c-Met to increase their tumor-targeting capability, and these modified M-EVs were coated onto a poly(lactic-co-glycolic acid) nanoplatform for delivery to triple-negative breast cancer. This modified M-EVs system significantly improved the cellular uptake efficiency and antitumor efficacy of doxorubicin [160]. DC-derived EVs (DC-EVs) contain co-stimulatory molecules, integrin av $\beta 2$, intercellular adhesion molecule 1 (ICAM1), and other components involved in cell-cell interactions [161], which allows DC-EVs to control tumor immune escape by modulating immune stimulation, thereby inhibiting tumor progression [162]. This property of DC-EVs has been investigated to load drugs to enhance antitumor effects. For instance, the loading of fetoprotein into DC-EVs induced antigen-specific immune responses, including the upregulation of IFN- $\gamma$ and IL-2 and the downregulation of Tregs recruitment, which inhibited HCC growth [163]. In addition, EVs purified from DCs loaded with antigens and matured with the Toll-like receptor 3 (TLR3) ligand poly (I:C) strongly stimulated the proliferation of $\mathrm{CD} 8^{+}$and $\mathrm{CD} 4^{+} \mathrm{T}$ cells and recruited $\mathrm{CD}^{+} \mathrm{T}$ cells and natural killer (NK) cells to tumors, 
thereby enhancing the antitumor functions of the EVs and inhibiting melanoma growth [164]. Meanwhile, EVs derived from $\mathrm{T}$ cells and NK cells also inhibited tumor progression by responding to specific antigens and producing cytokines that modulated the immune response. EVs derived from genetically engineered chimeric antigen receptor (CAR)-T cells express CAR, CD63, CD3, and $\mathrm{C}-\mathrm{X}-\mathrm{C}$ motif chemokine receptor 4 (CXCR4), which allows them to exert potent antitumor effects [165]. Moreover, EVs secreted by NK cells (NK-EVs) can exert cytolytic effects on tumor tissues [166], while miRNAloaded biomimetic core-shell nanoparticles that act together with modified NK-EVs increased drug targeting and miRNA delivery efficiency in neuroblastoma cells, resulting in the dual inhibition of tumor growth [167].

\section{EVs-based drug co-delivery system}

To further enhance the delivery effect of EVs, research attention has increasingly focused on the development of EVs-nanodrug co-delivery systems (Fig. 3). These systems can enhance drug delivery efficiency by combining the advantages of EVs and those of inorganic nanocarriers. Combining EVs with hydrogels and liposomes is increasingly common. Compared with existing standalone inorganic nanocarriers such as gold nanoparticles and therapeutic nano-bioconjugates, this combinatorial drug delivery approach improves EVs targeting and drug encapsulation efficiency [168-173]. Furthermore, the exceptional biocompatibility of the co-loading system renders it suitable for tumor-targeted therapy.
Hydrogels are three-dimensional network structures with good biocompatibility and high water content [174]. They can serve as drug carriers for tumor therapy as they have properties similar to those of the extracellular matrix [175]. However, the low stability, poor mechanical properties, and poor cell adhesion properties of natural hydrogels limit their application as drug carriers [176]. Synthetic hydrogels have received increasing attention based on the reliability of their sources, long shelf life, and low risk of immunogenicity [177]. The most commonly employed hydrogel synthesis system involves the incorporation of EVs. For example, in one system, thioglycolic acid, gelatin, and heparin were used as the main components and polyethylene glycol diacrylate (PEGDA) as the gelling agent; BM-MSCs-EVs were then incorporated into this polymer to complete the preparation of the drug delivery system [178]. In addition, the integration of EVs and their parent stem cells into hydrogels has been proposed as a means of achieving sustained EVs delivery [179]. Hydrogel-EVs systems have shown promise in tumor treatment. For instance, a hydrogelEVs system developed for the delivery of doxorubicin and celecoxib showed good drug delivery efficiency and significantly inhibited tumor growth [180]. Additionally, the combined application of hydrogel and human umbilical cord MSC-EVs (hUC-MSC-EVs) to deliver drugs to sites of disease led to a significant increase in drug delivery efficiency, which provides guidance for tumor-targeted therapy despite this effect referring to a model of diabetes [181].

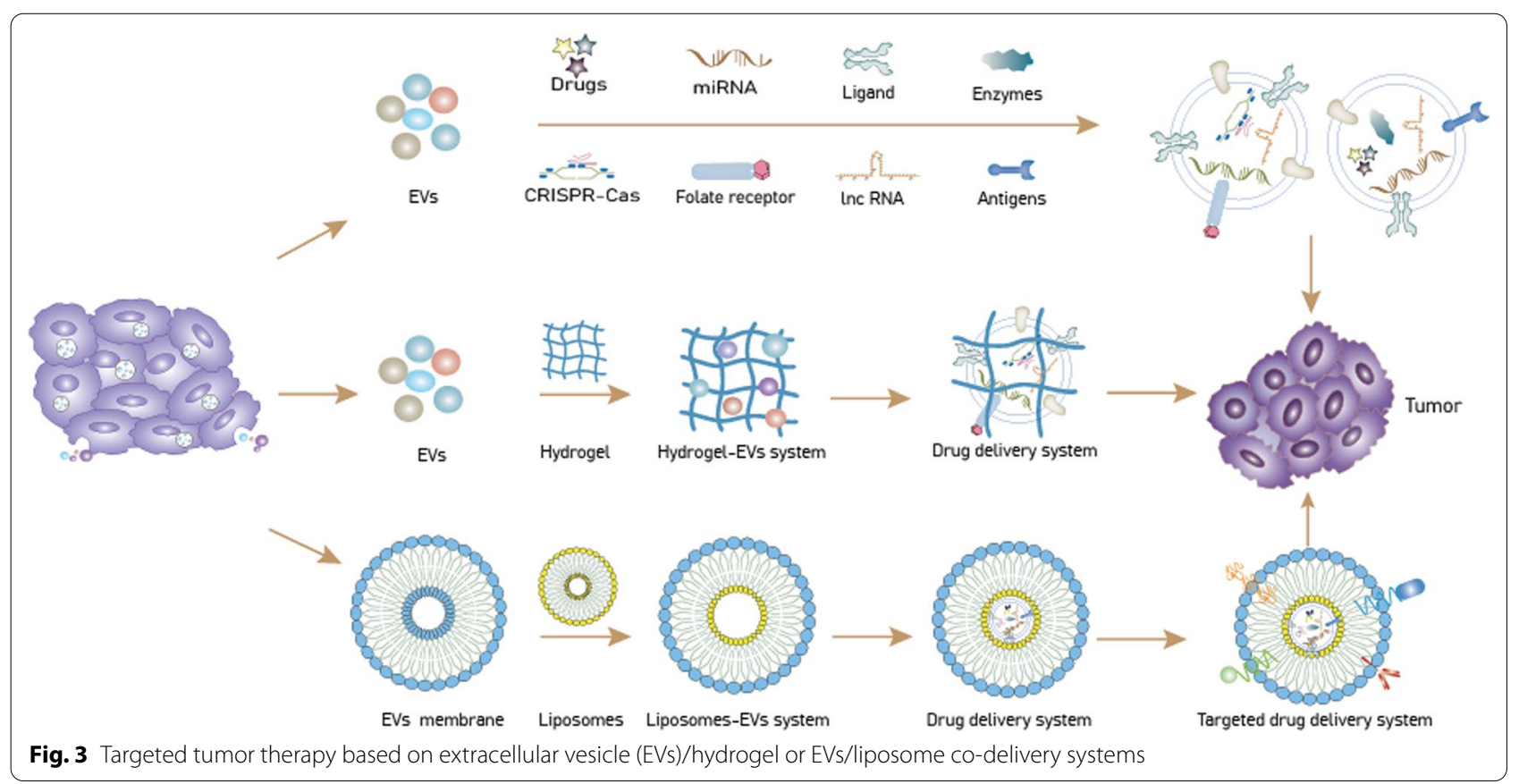


Liposomes are tiny vesicles enclosed in a membrane bilayer consisting mainly of phospholipids and cholesterol that can encapsulate drugs and serve as valuable drug delivery systems [182]. However, instability, lack of drug encapsulation repeatability, a lack of particle size control, and a short half-life are all factors that have hampered the development of liposome-based therapy [183-185]. EVs have many similarities with liposomes and these similarities allow for the use of liposomerelated technology to design EVs, such as when EVs and liposomes are fused to construct a drug co-delivery system. Compared with stand-alone liposome drug delivery systems, liposome-EVs formulations exhibit greater anticancer efficacy owing to slower drug release and longer drug half-life [186, 187]. Moreover, the fusion of EVs with liposomes increases loading capacity while retaining the targeting ability of EVs [75]. In one study, the authors fused liposomes with MSC-EVs and obtained a hybrid liposome-EVs system that was then loaded with miR-34a. The system was shown to significantly enhance miRNA delivery efficiency and delay the progression of breast cancer [77]. Additionally, the synthesis of thermosensitive hybrid EVs-liposome nanoparticles loaded with doxorubicin led to a significant improvement in the efficiency of chemotherapeutic drug delivery and inhibited the growth of metastatic peritoneal cancer [188]. Surprisingly, the biocompatibility of the EVs prevents the drug co-delivery system from being eliminated by the immune system in vivo, hence retaining the stability of the drug delivery system. Microfluidic and lab-on-a-chip technologies have enabled the production of liposomes of controllable size using simple methods. Such uniform liposomes make the large-scale manufacture of EVsliposome drug delivery devices possible [189]. Of note, the hydrophobicity of lipid molecules makes the fusion of liposomes and EVs difficult; accordingly, a new strategy for the preparation of liposome-EVs fusions has been proposed, namely, the use of freeze-thaw cycles [190]. Overall, liposome-EVs systems have excellent potential for targeted tumor therapy.

\section{Conclusions}

Because of their excellent properties, EVs may be an ideal drug delivery vehicle for tumor therapy. The engineering of EVs for the treatment of tumors also shows promise and has been widely studied owing to its superiority over natural EVs. In this review, we discussed techniques commonly used for the isolation of EVs, specific EVs modifications, and the therapeutic effects of engineered EVs on tumors. The presented evidence highlighted the utility of using EVs for targeted tumor therapy. However, although EVs have been investigated in clinical trials, further research is warranted to confirm their excellent antitumor therapeutic effects. Owing to differences in the biological properties of EVs secreted by different cells, there is currently no unified standard for their isolation. In addition, the high cost and unsatisfactory isolation efficiency are currently the primary factors limiting large-scale EVs production. For instance, ultracentrifuge-based EVs isolation alone may suffice for preclinical analysis but not for realworld clinical application because of the presence of co-isolates. Furthermore, isolation techniques such as immunochromatography and ultrafiltration are timeconsuming and are not suitable for large-scale sample isolation. Therefore, it is advisable to combine different isolation techniques to improve separation efficiency, such as ultracentrifugation to remove impurities followed by immunoaffinity chromatography. Microfluidic technology has been used to isolate and purify EVs from culture medium, and the structural integrity and functional stability of the isolated EVs were retained with this method. This approach is characterized by simplicity, high sensitivity, and low cost, showing excellent application potential. Nevertheless, the EVs isolation efficiency associated with this technique requires further improvement [191, 192].

For EVs modification, it is necessary to fully understand the composition of the EVs membrane at the target site, and select the appropriate targeting ligands. This is important to avoid changes in the charge on the EVs membrane during the modification process and maintain its physicochemical stability. Notably, genetic engineering can only be used to modify encoded proteins or polypeptides. When performing modifications at the genetic level, the functional stability of EVs membrane proteins must be maintained. The modification of EVs surface proteins using amino acids, lipids, and polysaccharides requires suitable chemical and physical treatment for a firm attachment. Because the treated EVs may contain high levels of impurities, EVs must be isolated and purified to ensure safety. Further research on EVs modification methods is warranted. For drug loading, chemotherapeutic agents are currently the primary choice, and engineering modifications has improved the targeting and drug loading efficiency of EVs. Furthermore, using engineered modifications, gene therapy also exhibits tumor-targeting therapeutic potential, highlighting the good application prospects of EVs loaded with RNAs, nucleic acids, and other contents. Despite these observations, pre- and clinical applications of engineered EVs face many challenges. Drug delivery efficiency, scalability, stability, and tumor targeting potential of engineered EVs require optimization, such as how to improve the targeting of EVs by chemical modification while maintaining their membrane integrity. 
Co-delivery systems may be an option for further improving EVs drug delivery efficiency and tumor targeting abilities. In addition to hydrogels and liposomes, multiple inorganic nanocarriers, such as dendrimers and micelles, have also received attention for cellular targeting, high-dose drug delivery, and gene therapy payloads [193]. Relatively few studies have investigated EVs-based co-delivery systems given the associated limitations, which include the complexity of technical manipulation. However, these nanocarrier-EVs systems have great potential for drug delivery in oncology and merit further exploration. The effect of EVs secreted by different cells on tumor progression varies. Thus, selecting EVs with antitumor effects as drug carriers may improve the efficiency of antitumor therapy. MSCs have a robust EVs production capacity compared with most other cells [194], while the low immunogenicity of MSC-EVs allows them to avoid activating the immune response and, consequently, clearance by the immune system [195]. In addition, MSC-EVs have a unique homing ability, a property that can be harnessed for targeted tumor therapy. These advantages make EVs the primary choice as drug delivery systems for targeted tumor therapy. EVs secreted by other immune cells, such as M1-EVs, DC-EVs, and NK-EVs, can inhibit tumor progression by affecting interactions within the tumor microenvironment; accordingly, these EVs also have excellent potential as drug delivery systems.

In conclusion, the use of modified EVs has the potential to contribute greatly to tumor therapy. As the demand for precise tumor treatment increases, there is an urgent need to understand the mechanisms associated with EVs biogenesis and transport, as well as those involved in EVs signaling after modification. We hope that this review will promote the clinical application of EVs.

\section{Abbreviations}

BM-MSCs-EVs: Extracellular vesicles derived from bone marrow mesenchymal stem cells; CCT2: Chaperonin containing TCP1 subunit 2; CXCR4: C-X-C motif chemokine receptor 4; DC: Dendritic cells; DC-EVs: Dendritic cells secreted extracellular vesicles; FBS: Fetal bovine serum; FR: Folate receptor; GPI: Glycosyl phosphatidyl inositol; HA: Hyaluronic acid; HCC: Hepatocellular carcinoma; HPL: Human platelet lysate; HS: Human serum; HYALs: Hyaluronidases; IncRNA: Long non-coding RNA; M-EVs: Extracellular vesicles from macrophages; miRNA: MicroRNA; MMP: Matrix metalloproteinases; MSCs: Mesenchymal stem cells; MSCs-EVs: Extracellular vesicles derived from mesenchymal stem cells; NK: Natural killer cells; NK-EVs: Natural killer cells secreted extracellular vesicles; PD-1: Programmed death-1; PD-L1: Programmed death-ligand 1; PEG: Polyethylene glycol; PTX: Paclitaxel; SIRPa: Signal regulatory protein alpha; Tu-EVs: Tumor-derived extracellular vesicles; Ti-EVs: Tissue-derived extracellular vesicles; UC: Ultracentrifugation.
\end{abstract}

\section{Acknowledgements}

Not applicable.

\section{Authors' contributions}

FZ organized and wrote this review, JG collected data and provided editorial assistance, $\mathrm{XJ}$ and $\mathrm{ZY}$ provided the design, revision and funding of the manuscript. All authors made substantial, direct and intellectual contribution to the review. All authors read and approved the final manuscript.

\section{Funding}

This study was supported by grants from the National Natural Science Foundation of China (Nos. 81672877, 82173194) and the Key research project of Liaoning Provincial Department of Education of China (ZD2020004).

\section{Availability of data and materials \\ Not applicable.}

\section{Declarations}

Ethics approval and consent to participate

Not applicable.

\section{Consent for publication}

Not applicable.

\section{Competing interests}

The authors declare that they have no competing interests.

Received: 25 November 2021 Accepted: 15 February 2022

Published online: 21 February 2022

\section{References}

1. Torre LA, Bray F, Siegel RL, Ferlay J, Lortet-Tieulent J, Jemal A. Global cancer statistics, 2012. CA Cancer J Clin. 2015;65:87-108. https://doi. org/10.3322/caac.21262.

2. Ivey JW, Bonakdar M, Kanitkar A, Davalos RV, Verbridge SS. Improving cancer therapies by targeting the physical and chemical hallmarks of the tumor microenvironment. Cancer Lett. 2016;380:330-9. https://doi. org/10.1016/j.canlet.2015.12.019.

3. Dash SK, Chattopadhyay S, Ghosh T, Dash SS, Tripathy S, Das B, Bag BG, Das D, Roy S. Self-assembled betulinic acid protects doxorubicin induced apoptosis followed by reduction of ROS-TNF-a-caspase-3 activity. Biomed Pharmacother. 2015;72:144-57. https://doi.org/10. 1016/j.biopha.2015.04.017.

4. Elsharkasy OM, Nordin JZ, Hagey DW, de Jong OG, Schiffelers RM, Andaloussi SE, Vader P. Extracellular vesicles as drug delivery systems: why and how? Adv Drug Deliv Rev. 2020;159:332-43. https://doi.org/ 10.1016/.addr.2020.04.004.

5. Hanayama R. Emerging roles of extracellular vesicles in physiology and disease. J Biochem. 2021;169:135-8. https://doi.org/10.1093/jb/mvaa1 38.

6. Ovchinnikova LA, Terekhov SS, Ziganshin RH, Bagrov DV, Filimonova IN, Zalevsky AO, Lomakin YA. Reprogramming extracellular vesicles for protein therapeutics delivery. Pharmaceutics. 2021. https://doi.org/10. 3390/pharmaceutics13060768.

7. Vader P, Mol EA, Pasterkamp G, Schiffelers RM. Extracellular vesicles for drug delivery. Adv Drug Deliv Rev. 2016;106:148-56. https://doi.org/10. 1016/j.addr.2016.02.006.

8. van Niel G, D'Angelo G, Raposo S. hedding light on the cell biology of extracellular vesicles, nature reviews. Mol Cell Biol. 2018;19:213-28. https://doi.org/10.1038/nrm.2017.125.

9. de Abreu RC, Fernandes H, da Costa Martins PA, Sahoo S, Emanueli C, Ferreira L. Native and bioengineered extracellular vesicles for cardiovascular therapeutics, nature reviews. Cardiology. 2020;17:685-97. https:// doi.org/10.1038/s41569-020-0389-5.

10. Li S, Xu J, Qian J, Gao X. Engineering extracellular vesicles for cancer therapy: recent advances and challenges in clinical translation. Biomater Sci. 2020:8:6978-91. https://doi.org/10.1039/d0bm01385d.

11. Nie W, Wu G, Zhong H, Xie HY. Membrane vesicles nanotheranostic systems: sources, engineering methods, and challenges. Biomed Mater (Bristol, England). 2021;16: 022009. https://doi.org/10.1088/1748-605X/ abd2c8.

12. Théry C, Witwer KW, Aikawa E, Alcaraz MJ, Anderson JD, Andriantsitohaina R, Antoniou A, Arab T, Archer F, Atkin-Smith GK, Ayre DC, Bach 
JM, Bachurski D, Baharvand H, Balaj L, Baldacchino S, Bauer NN, Baxter AA, Bebawy M, Beckham C, Bedina Zavec A, Benmoussa A, Berardi AC, Bergese P, Bielska E, Blenkiron C, Bobis-Wozowicz S, Boilard E, Boireau W, Bongiovanni A, Borràs FE, Bosch S, Boulanger CM, Breakefield X, Breglio AM, Brennan M, Brigstock DR, Brisson A, Broekman ML, Bromberg JF, Bryl-Górecka P, Buch S, Buck AH, Burger D, Busatto S, Buschmann D, Bussolati B, Buzás El, Byrd JB, Camussi G, Carter DR, Caruso S, Chamley LW, Chang YT, Chen C, Chen S, Cheng L, Chin AR, Clayton A, Clerici SP, Cocks A, Cocucci E, Coffey RJ, Cordeiro-da-Silva A, Couch Y, Coumans FA, Coyle B, Crescitelli R, Criado MF, D'Souza-Schorey C, Das S, Datta Chaudhuri A, de Candia P, De Santana EF, De Wever O, Del Portillo HA, Demaret T, Deville S, Devitt A, Dhondt B, Di Vizio D, Dieterich LC, Dolo V, Dominguez Rubio AP, Dominici M, Dourado MR, Driedonks TA, Duarte FV, Duncan HM, Eichenberger RM, Ekström K, El Andaloussi S, Elie-Caille C, Erdbrügger U, Falcón-Pérez JM, Fatima F, Fish JE, Flores-Bellver M, Försönits A, Frelet-Barrand A, Fricke F, Fuhrmann G, Gabrielsson S, Gámez-Valero A, Gardiner C, Gärtner K, Gaudin R, Gho YS, Giebel B, Gilbert C, Gimona M, Giusti I, Goberdhan DC, Görgens A, Gorski SM, Greening DW, Gross JC, Gualerzi A, Gupta GN, Gustafson D, Handberg A, Haraszti RA, Harrison P, Hegyesi H, Hendrix A, Hill AF, Hochberg FH, Hoffmann KF, Holder B, Holthofer H, Hosseinkhani B, Hu G, Huang Y, Huber V, Hunt S, Ibrahim AG, Ikezu T, Inal JM, Isin M, Ivanova A, Jackson HK, Jacobsen S, Jay SM, Jayachandran M, Jenster G, Jiang L, Johnson SM, Jones JC, Jong A, Jovanovic-Talisman T, Jung S, Kalluri R, Kano SI, Kaur S, Kawamura Y, Keller ET, Khamari D, Khomyakova E, Khvorova A, Kierulf P, Kim KP, Kislinger T, Klingeborn M, Klinke DJ 2nd, Kornek M, Kosanović MM, Kovács FÁ, Krämer-Albers EM, Krasemann S, Krause M, Kurochkin IV, Kusuma GD, Kuypers S, Laitinen S, Langevin SM, Languino LR, Lannigan J, Lässer C, Laurent LC, Lavieu G, Lázaro-Ibáñez E, Le Lay S, Lee MS, Lee YXF, Lemos DS, Lenassi M, Leszczynska A, Li IT, Liao K, Libregts SF, Ligeti E, Lim R, Lim SK, Linē A, Linnemannstöns K, Llorente A, Lombard CA, Lorenowicz MJ, Lörincz MÁ, Lötvall J, Lovett J, Lowry MC, Loyer X, Lu Q, Lukomska B, Lunavat TR, Maas SL, Malhi H, Marcilla A, Mariani J, Mariscal J, Martens-Uzunova ES, Martin-Jaular L, Martinez MC, Martins VR, Mathieu M, Mathivanan S, Maugeri M, McGinnis LK, McVey MJ, Meckes DG Jr, Meehan KL, Mertens I, Minciacchi VR, Möller A, Møller Jørgensen M, Morales-Kastresana A, Morhayim J, Mullier F, Muraca M, Musante L, Mussack V, Muth DC, Myburgh KH, Najrana T, Nawaz M, Nazarenko I, Nejsum P, Neri C, Neri T, Nieuwland R, Nimrichter L, Nolan JP, Nolte-'t Hoen EN, Noren Hooten N, O'Driscoll L, O'Grady T, O'Loghlen A, Ochiya T, Olivier M, Ortiz A, Ortiz LA, Osteikoetxea X, Østergaard O, Ostrowski M, Park J, Pegtel DM, Peinado H, Perut F, Pfaffl MW, Phinney DG, Pieters BC, Pink RC, Pisetsky DS, Pogge von Strandmann E, Polakovicova I, Poon IK, Powell BH, Prada I, Pulliam L, Quesenberry P, Radeghieri A, Raffai RL, Raimondo S, Rak J, Ramirez MI, Raposo G, Rayyan MS, Regev-Rudzki N, Ricklefs FL, Robbins PD, Roberts DD, Rodrigues SC, Rohde E, Rome S, Rouschop KM, Rughetti A, Russell AE, Saá P, Sahoo S, Salas-Huenuleo E, Sánchez C, Saugstad JA, Saul MJ, Schiffelers RM, Schneider R, Schøyen TH, Scott A, Shahaj E, Sharma S, Shatnyeva O, Shekari F, Shelke GV, Shetty AK, Shiba K, Siljander PR, Silva AM, Skowronek A, Snyder OL 2nd, Soares RP, Sódar BW, Soekmadji C, Sotillo J, Stahl PD, Stoorvogel W, Stott SL, Strasser EF, Swift S, Tahara H, Tewari M, Timms K, Tiwari S, Tixeira R, Tkach M, Toh WS, Tomasini R, Torrecilhas AC, Tosar JP, Toxavidis V, Urbanelli L, Vader P, van Balkom BW, van der Grein SG, Van Deun J, van Herwijnen MJ, Van Keuren-Jensen K, van Niel G, van Royen ME, van Wijnen AJ, Vasconcelos MH, Vechetti IJ Jr, Veit TD, Vella LJ, Velot É, Verweij FJ, Vestad B, Viñas JL, Visnovitz T, Vukman KV, Wahlgren J, Watson DC, Wauben MH, Weaver A, Webber JP, Weber V, Wehman AM, Weiss DJ, Welsh JA, Wendt S, Wheelock AM, Wiener Z, Witte L, Wolfram J, Xagorari A, Xander P, Xu J, Yan X, Yáñez-Mó M, Yin H, Yuana Y, Zappulli V, Zarubova J, Žèkas V, Zhang JY, Zhao Z, Zheng L, Zheutlin AR, Zickler AM, Zimmermann P, Zivkovic AM, Zocco D, Zuba-Surma EK. Minimal information for studies of extracellular vesicles 2018 (MISEV2018): a position statement of the International Society for Extracellular Vesicles and update of the MISEV2014 guidelines. J Extracell Vesicles. 2018;7:1535750. https://doi.org/10.1080/20013078.2018.1535750.

13. Wiklander OPB, Brennan M, Lötvall J, Breakefield XO, El Andaloussi S. Advances in therapeutic applications of extracellular vesicles. Sci Ttransl Med. 2019. https://doi.org/10.1126/scitranslmed.aav8521.
14. Grange C, Skovronova R, Marabese F, Bussolati B. Stem cell-derived extracellular vesicles and kidney regeneration. Cells. 2019. https://doi. org/10.3390/cells8101240.

15. Joshi BS, de Beer MA, Giepmans BNG, Zuhorn IS. Endocytosis of extracellular vesicles and release of their cargo from endosomes. ACS Nano. 2020;14:4444-55. https://doi.org/10.1021/acsnano.9b10033.

16. Pegtel DM, Gould SJ. Exosomes. Annu Rev Biochem. 2019;88:487-514. https://doi.org/10.1146/annurev-biochem-013118-111902.

17. Andaloussi SEL, Mäger I, Breakefield XO, Wood MJA. Extracellular vesicles: biology and emerging therapeutic opportunities. Nat Rev Drug Discov. 2013;12(5):347-57. https://doi.org/10.1038/nrd3978.

18. Yang D, Zhang W, Zhang H, Zhang F, Chen L, Ma L, Larcher LM, Chen S, Liu N, Zhao Q, Tran PHL, Chen C, Veedu RN, Wang T. Progress, opportunity, and perspective on exosome isolation-efforts for efficient exosome-based theranostics. Theranostics. 2020;10:3684-707. https:// doi.org/10.7150/thno.41580.

19. Xu R, Greening DW, Zhu HJ, Takahashi N, Simpson RJ. Extracellular vesicle isolation and characterization: toward clinical application. J Clin Investig. 2016;126:1152-62. https://doi.org/10.1172/jci81129.

20. Li SR, Man QW, Gao X, Lin H, Wang J, Su FC, Wang HQ, Bu LL, Liu B, Chen G. Tissue-derived extracellular vesicles in cancers and non-cancer diseases: present and future. J Extracell Vesicles. 2021;10: e12175. https:// doi.org/10.1002/jev2.12175.

21. Staubach S, Bauer FN, Tertel T, Börger V, Stambouli O, Salzig D, Giebel B. Scaled preparation of extracellular vesicles from conditioned media. Adv Drug Deliv Rev. 2021;177: 113940. https://doi.org/10.1016/j.addr. 2021.113940.

22. Hemeda H, Giebel B, Wagner W. Evaluation of human platelet lysate versus fetal bovine serum for culture of mesenchymal stromal cells. Cytotherapy. 2014. https://doi.org/10.1016/j.jcyt.2013.11.004.

23. Tateishi K, Ando W, Higuchi C, Hart DA, Hashimoto J, Nakata K, Yoshikawa H, Nakamura N. Comparison of human serum with fetal bovine serum for expansion and differentiation of human synovial MSC: potential feasibility for clinical applications. Cell Transplant. 2008;17:549-57. https://doi.org/10.3727/096368908785096024.

24. Aldahmash A, Haack-Sørensen M, Al-Nbaheen M, Harkness L, Abdallah $B M$, Kassem M. Human serum is as efficient as fetal bovine serum in supporting proliferation and differentiation of human multipotent stromal (mesenchymal) stem cells in vitro and in vivo. Stem Cell Rev Rep. 2011;7:860-8. https://doi.org/10.1007/s12015-011-9274-2.

25. Mannello F, Tonti GA. Concise review: no breakthroughs for human mesenchymal and embryonic stem cell culture: conditioned medium, feeder layer, or feeder-free; medium with fetal calf serum, human serum, or enriched plasma; serum-free, serum replacement nonconditioned medium, or ad hoc formula? All that glitters is not gold! Stem Cells (Dayton, Ohio). 2007;25:1603-9. https://doi.org/10.1634/stemcells. 2007-0127.

26. Salzig D, Leber J, Merkewitz K, Lange MC, Köster N, Czermak P. Attachment, growth, and detachment of human mesenchymal stem cells in a chemically defined medium. Stem Cells Int. 2016;2016:5246584. https:// doi.org/10.1155/2016/5246584.

27. Ragni E, Perucca Orfei C, De Luca P, Mondadori C, Viganò M, Colombini A, de Girolamo L. Inflammatory priming enhances mesenchymal stromal cell secretome potential as a clinical product for regenerative medicine approaches through secreted factors and EV-miRNAs: the example of joint disease. Stem Cell Res Therapy. 2020;11:165. https:// doi.org/10.1186/s13287-020-01677-9.

28. Almeria C, Weiss R, Roy M, Tripisciano C, Kasper C, Weber V, Egger D. Hypoxia conditioned mesenchymal stem cell-derived extracellular vesicles induce increased vascular tube formation in vitro. Front Bioeng Biotechnol. 2019;7:292. https://doi.org/10.3389/fbioe.2019.00292.

29. Jingushi K, Uemura M, Ohnishi N, Nakata W, Fujita K, Naito T, Fujii R, Saichi N, Nonomura N, Tsujikawa K, Ueda K. Extracellular vesicles isolated from human renal cell carcinoma tissues disrupt vascular endothelial cell morphology via azurocidin. Int J Cancer. 2018;142:607-17. https:// doi.org/10.1002/ijc.31080.

30. Huang Z, Xu A. Adipose extracellular vesicles in intercellular and inter-organ crosstalk in metabolic health and diseases. Front Immunol. 2021;12:608680. https://doi.org/10.3389/fimmu.2021.608680.

31. Belov L, Matic KJ, Hallal S, Best OG, Mulligan SP, Christopherson RI. Extensive surface protein profiles of extracellular vesicles from cancer 
cells may provide diagnostic signatures from blood samples. J Extracell Vesicles. 2016;5:25355. https://doi.org/10.3402/jev.v5.25355.

32. Crescitelli R, Lässer C, Jang SC, Cvjetkovic A, Malmhäll C, Karimi N, Höög JL, Johansson I, Fuchs J, Thorsell A, Gho YS, Olofsson Bagge R, Lötvall J. Subpopulations of extracellular vesicles from human metastatic melanoma tissue identified by quantitative proteomics after optimized isolation. J Extracell Vesicles. 2020;9:1722433. https://doi.org/10.1080/ 20013078.2020.1722433.

33. Zhu L, Xu N, Zhang ZL, Zhang TC. Cell derived extracellular vesicles: from isolation to functionalization and biomedical applications. Biomater Sci. 2019;7:3552-65. https://doi.org/10.1039/c9bm00580c.

34. Bobrie A, Colombo M, Krumeich S, Raposo G, Théry C. Diverse subpopulations of vesicles secreted by different intracellular mechanisms are present in exosome preparations obtained by differential ultracentrifugation. J Extracell Vesicles. 2012. https://doi.org/10.3402/jev.v1 i0.18397.

35. Wang W, Luo J, Wang S. Recent progress in isolation and detection of extracellular vesicles for cancer diagnostics. Adv Healthc Mater. 2018;7: e1800484. https://doi.org/10.1002/adhm.201800484.

36. Momen-Heravi F. Isolation of extracellular vesicles by ultracentrifugation. Methods Mol Biol (Clifton NJ). 2017;1660:25-32. https://doi.org/10. 1007/978-1-4939-7253-1_3.

37. Cvjetkovic A, Lötvall J, Lässer C. The influence of rotor type and centrifugation time on the yield and purity of extracellular vesicles. J Extracell Vesicles. 2014. https://doi.org/10.3402/jev.v3.23111.

38. Livshits MA, Khomyakova E, Evtushenko EG, Lazarev VN, Kulemin NA, Semina SE, Generozov EV, Govorun VM. Isolation of exosomes by differential centrifugation: theoretical analysis of a commonly used protocol. Sci Rep. 2015;5:17319. https://doi.org/10.1038/srep17319.

39. Lobb RJ, Becker M, Wen SW, Wong CS, Wiegmans AP, Leimgruber A Moller A. Optimized exosome isolation protocol for cell culture supernatant and human plasma. J Extracell Vesicles. 2015;4:27031. https:// doi.org/10.3402/jev.v4.27031.

40. Kosanović M, Milutinović B, Goč S, Mitić N, Janković M. lon-exchange chromatography purification of extracellular vesicles. Biotechniques. 2017;63:65-71. https://doi.org/10.2144/000114575.

41. Asaadi A, Dolatabad NA, Atashi H, Raes A, Van Damme P, Hoelker M, Hendrix A, Pascottini OB, Van Soom A, Kafi M, Pavani KC. Extracellular vesicles from follicular and ampullary fluid isolated by density gradient ultracentrifugation improve bovine embryo development and quality. Int J Mol Sci. 2021. https://doi.org/10.3390/ijms22020578.

42. Onódi Z, Pelyhe C, Terézia Nagy C, Brenner GB, Almási L, Kittel Á, Manček-Keber M, Ferdinandy P, Buzás El, Giricz Z. Isolation of highpurity extracellular vesicles by the combination of iodixanol density gradient ultracentrifugation and bind-elute chromatography from blood plasma. Front Physiol. 2018;9:1479. https://doi.org/10.3389/fphys. 2018.01479.

43. Van Deun J, Mestdagh P, Sormunen R, Cocquyt V, Vermaelen K, Vandesompele J, Bracke M, De Wever O, Hendrix A. The impact of disparate isolation methods for extracellular vesicles on downstream RNA profiling. J Extracell Vesicles. 2014. https://doi.org/10.3402/jev.v3.24858.

44. Zeringer E, Li M, Barta T, Schageman J, Pedersen KW, Neurauter A, Magdaleno S, Setterquist R, Vlassov AV. Methods for the extraction and RNA profiling of exosomes. World J Methodol. 2013;3:11-8. https://doi. org/10.5662/wjm.v3.i1.11.

45. Kornilov R, Puhka M, Mannerström B, Hiidenmaa H, Peltoniemi H, Siljander P, Seppänen-Kaijansinkko R, Kaur S. Efficient ultrafiltration-based protocol to deplete extracellular vesicles from fetal bovine serum. J Extracell Vesicles. 2018;7:1422674. https://doi.org/10.1080/20013078. 2017.1422674.

46. Oeyen E, Van Mol K, Baggerman G, Willems H, Boonen K, Rolfo C, Pauwels P, Jacobs A, Schildermans K, Cho WC, Mertens I. Ultrafiltration and size exclusion chromatography combined with asymmetrical-flow field-flow fractionation for the isolation and characterisation of extracellular vesicles from urine. J Extracell Vesicles. 2018;7:1490143. https:// doi.org/10.1080/20013078.2018.1490143.

47. Benedikter BJ, Bouwman FG, Vajen T, Heinzmann ACA, Grauls G, Mariman EC, Wouters EFM, Savelkoul PH, Lopez-lglesias C, Koenen RR, Rohde GGU, Stassen FRM. Ultrafiltration combined with size exclusion chromatography efficiently isolates extracellular vesicles from cell culture media for compositional and functional studies. Sci Rep. 2017;7:15297. https://doi.org/10.1038/s41598-017-15717-7.
48. Guerreiro EM, Vestad B, Steffensen LA, Aass HCD, Saeed M, Øvstebø R, Costea DE, Galtung HK, Søland TM. Efficient extracellular vesicle isolation by combining cell media modifications, ultrafiltration, and size-exclusion chromatography. PLOS ONE. 2018;13: e0204276. https://doi.org/10.1371/journal.pone.0204276.

49. Kim K, Park J, Jung JH, Lee R, Park JH, Yuk JM, Hwang H, Yeon JH. Cyclic tangential flow filtration system for isolation of extracellular vesicles. APL Bioeng. 2021;5: 016103. https://doi.org/10.1063/5.00377 68.

50. Soares Martins T, Catita J, Martins Rosa I, Silva OABdCE, Henriques AG. Exosome isolation from distinct biofluids using precipitation and column-based approaches. PLoS ONE. 2018;13: e0198820. https:// doi.org/10.1371/journal.pone.0198820.

51. Xu R, Greening DW, Rai A, Ji H, Simpson RJ. Highly-purified exosomes and shed microvesicles isolated from the human colon cancer cell line LIM1863 by sequential centrifugal ultrafiltration are biochemically and functionally distinct. Methods (San Diego Calif). 2015;87:11-25. https://doi.org/10.1016/j.ymeth.2015.04.008.

52. Böing AN, van der Pol E, Grootemaat AE, Coumans FA, Sturk A, Nieuwland R. Single-step isolation of extracellular vesicles by sizeexclusion chromatography. J Extracell Vesicles. 2014. https://doi.org/ 10.3402/jev.v3.23430.

53. Hurwitz SN, Meckes DG Jr. An adaptable polyethylene glycol-based workflow for proteomic analysis of extracellular vesicles. Methods Mol Biol (Clifton NJ). 2017;1660:303-17. https://doi.org/10.1007/9781-4939-7253-1_25.

54. Sim SL, He T, Tscheliessnig A, Mueller M, Tan RB, Jungbauer A. Protein precipitation by polyethylene glycol: a generalized model based on hydrodynamic radius. J Biotechnol. 2012;157:315-9. https://doi.org/ 10.1016/j.jbiotec.2011.09.028.

55. Kalluri R, LeBleu VS. The biology, function, and biomedical applications of exosomes. Science. 2020. https://doi.org/10.1126/science. aau6977.

56. Wyciszkiewicz A, Kalinowska-Łyszczarz A, Nowakowski B, Kaźmierczak K, Osztynowicz K, Michalak S. Expression of small heat shock proteins in exosomes from patients with gynecologic cancers. Sci Rep. 2019;9:9817. https://doi.org/10.1038/s41598-019-46221-9.

57. Lane RE, Korbie D, Trau M, Hill MM. Purification protocols for extracellular vesicles. Methods Mol Biol (Clifton NJ). 2017;1660:111-30. https:// doi.org/10.1007/978-1-4939-7253-1_10.

58. Li P, Kaslan M, Lee SH, Yao J, Gao Z. Progress in exosome isolation techniques. Theranostics. 2017;7:789-804. https://doi.org/10.7150/thno. 18133.

59. Bijnsdorp IV, Maxouri O, Kardar A, Schelfhorst T, Piersma SR, Pham TV, Vis $A$, van Moorselaar RJ, Jimenez CR. Feasibility of urinary extracellular vesicle proteome profiling using a robust and simple, clinically applicable isolation method. J Extracell Vesicles. 2017;6:1313091. https://doi. org/10.1080/20013078.2017.1313091.

60. Mondal SK, Whiteside TL. Immunoaffinity-based isolation of melanoma cell-derived and T cell-derived exosomes from plasma of melanoma patients. Methods Mol Biol (Clifton NJ). 2021;2265:305-21. https://doi. org/10.1007/978-1-0716-1205-7_23.

61. Song Z, Mao J, Barrero RA, Wang P, Zhang F, Wang T. Development of a CD63 aptamer for efficient cancer immunochemistry and immunoaffinity-based exosome isolation. Molecules (Basel Switzerland). 2020. https://doi.org/10.3390/molecules25235585.

62. Zhu J, Zhang J, Ji X, Tan Z, Lubman DM. Column-based technology for CD9-HPLC immunoaffinity isolation of serum extracellular vesicles. $J$ Proteome Res. 2021;20:4901-11. https://doi.org/10.1021/acs.jproteome. 1 c00549.

63. Fitzgerald J, Leonard P, Darcy E, Sharma S, O'Kennedy R. Immunoaffinity chromatography: concepts and applications. Methods Mol Biol (Clifton NJ). 2017;1485:27-51. https://doi.org/10.1007/978-1-4939-6412-3_3.

64. Wang T, Chen C, Larcher LM, Barrero RA, Veedu RN. Three decades of nucleic acid aptamer technologies: lessons learned, progress and opportunities on aptamer development. Biotechnol Adv. 2019;37:2850. https://doi.org/10.1016/j.biotechadv.2018.11.001.

65. Zhang K, Yue Y, Wu S, Liu W, Shi J, Zhang Z. Rapid capture and nondestructive release of extracellular vesicles using aptamer-based magnetic isolation. ACS Sens. 2019:4:1245-51. https://doi.org/10.1021/acssensors. 9b00060. 
66. Salafi T, Zeming KK, Zhang Y. Advancements in microfluidics for nanoparticle separation. Lab Chip. 2016;17:11-33. https://doi.org/10. 1039/c6lc01045h.

67. Lo TW, Zhu Z, Purcell E, Watza D, Wang J, Kang YT, Jolly S, Nagrath D, Nagrath S. Microfluidic device for high-throughput affinity-based isolation of extracellular vesicles. Lab Chip. 2020;20:1762-70. https:// doi.org/10.1039/c9lc01190k.

68. Davies RT, Kim J, Jang SC, Choi EJ, Gho YS, Park J. Microfluidic filtration system to isolate extracellular vesicles from blood. Lab Chip. 2012;12:5202-10. https://doi.org/10.1039/c2lc41006k.

69. Wang Z, Wu HJ, Fine D, Schmulen J, Hu Y, Godin B, Zhang JX, Liu X. Ciliated micropillars for the microfluidic-based isolation of nanoscale lipid vesicles. Lab Chip. 2013;13:2879-82. https://doi.org/10.1039/ c3lc41343h.

70. Lee $\mathrm{K}$, Shao H, Weissleder R, Lee H. Acoustic purification of extracellular microvesicles. ACS Nano. 2015;9:2321-7. https://doi.org/10.1021/ nn506538f.

71. Kang YT, Purcell E, Palacios-Rolston C, Lo TW, Ramnath N, Jolly S, Nagrath S. Isolation and profiling of circulating tumor-associated exosomes using extracellular vesicular lipid-protein binding affinity based microfluidic device. Small. 2019;15: e1903600. https://doi.org/ 10.1002/smll.201903600.

72. Dehghani M, Lucas K, Flax J, McGrath J, Gaborski T. Tangential flow microfluidics for the capture and release of nanoparticles and extracellular vesicles on conventional and ultrathin membranes. Adv Mater Technol. 2019. https://doi.org/10.1002/admt.201900539.

73. Zhao C, Busch DJ, Vershel CP, Stachowiak JC. Multifunctional transmembrane protein ligands for cell-specific targeting of plasma membrane-derived vesicles. Small. 2016;12:3837-48. https:/doi.org/ 10.1002/smll.201600493.

74. Bellavia D, Raimondo S, Calabrese G, Forte S, Cristaldi M, Patinella A, Memeo L, Manno M, Raccosta S, Diana P, Cirrincione G, Giavaresi G, Monteleone F, Fontana S, De Leo G, Alessandro R. Interleukin 3- receptor targeted exosomes inhibit in vitro and in vivo Chronic Myelogenous Leukemia cell growth. Theranostics. 2017;7:1333-45. https://doi.org/10.7150/thno.17092.

75. Rayamajhi S, Nguyen TDT, Marasini R, Aryal S. Macrophage-derived exosome-mimetic hybrid vesicles for tumor targeted drug delivery. Acta Biomater. 2019;94:482-94. https://doi.org/10.1016/j.actbio.2019. 05.054 .

76. Lee J, Lee H, Goh U, Kim J, Jeong M, Lee J, Park JH. Cellular engineering with membrane fusogenic liposomes to produce functionalized extracellular vesicles. ACS Appl Mater Interfaces. 2016;8:6790-5. https://doi.org/10.1021/acsami.6b01315.

77. Vakhshiteh F, Rahmani S, Ostad SN, Madjd Z, Dinarvand R, Atyabi F. Exosomes derived from miR-34a-overexpressing mesenchymal stem cells inhibit in vitro tumor growth: a new approach for drug delivery. Life Sci. 2021;266: 118871. https://doi.org/10.1016/j.Ifs.2020.118871.

78. Williams C, Royo F, Aizpurua-Olaizola O, Pazos R, Boons GJ, Reichardt NC, Falcon-Perez JM. Glycosylation of extracellular vesicles: current knowledge, tools and clinical perspectives. J Extracell Vesicles. 2018;7:1442985. https://doi.org/10.1080/20013078.2018.1442985.

79. Hung ME, Leonard JN. Stabilization of exosome-targeting peptides via engineered glycosylation. J Biol Chem. 2015;290:8166-72. https:// doi.org/10.1074/jbc.M114.621383.

80. Zhang J, Zhang Y, Luo C, Xia Y, Chen H, Wu X. Glycosyl-phosphatidylinositol-anchored interleukin-2 expressed on tumor-derived exosomes induces antitumor immune response in vitro. Tumori. 2010;96:452-9.

81. Raghav A, Jeong GB. A systematic review on the modifications of extracellular vesicles: a revolutionized tool of nano-biotechnology. J Nanobiotechnol. 2021;19:459. https://doi.org/10.1186/ s12951-021-01219-2.

82. Lin Y, Wu J, Gu W, Huang Y, Tong Z, Huang L, Tan J. Exosome-liposome hybrid nanoparticles deliver CRISPR/Cas9 system in MSCs. Adv Sci (Weinheim, Baden-Wurttemberg Germany). 2018;5:1700611. https:// doi.org/10.1002/advs.201700611.

83. Haney MJ, Klyachko NL, Zhao Y, Gupta R, Plotnikova EG, He Z, Patel T, Piroyan A, Sokolsky M, Kabanov AV, Batrakova EV. Exosomes as drug delivery vehicles for Parkinson's disease therapy. J Controll Release. 2015;207:18-30. https://doi.org/10.1016/j.jconrel.2015.03.033.
84. Kim H, Kim D, Nam H, Moon S, Kwon YJ, Lee JB. Engineered extracellular vesicles and their mimetics for clinical translation. Methods (San Diego, Calif). 2020;177:80-94. https://doi.org/10.1016/j.ymeth.2019.10.005.

85. Lamichhane TN, Raiker RS, Jay SM. Exogenous DNA loading into extracellular vesicles via electroporation is size-dependent and enables limited gene delivery. Mol Pharm. 2015;12:3650-7. https://doi.org/10. 1021/acs.molpharmaceut.5b00364.

86. Kooijmans SAA, Stremersch S, Braeckmans K, de Smedt SC, Hendrix A, Wood MJA, Schiffelers RM, Raemdonck K, Vader P. Electroporationinduced siRNA precipitation obscures the efficiency of siRNA loading into extracellular vesicles. J Control Release. 2013;172:229-38. https:// doi.org/10.1016/j.jconrel.2013.08.014.

87. Hood JL, Scott MJ, Wickline SA. Maximizing exosome colloidal stability following electroporation. Anal Biochem. 2014;448:41-9. https://doi. org/10.1016/j.ab.2013.12.001.

88. Momen-Heravi F, Bala S, Bukong T, Szabo G. Exosome-mediated delivery of functionally active miRNA-155 inhibitor to macrophages. Nanomed Nanotechnol Biol Med. 2014;10:1517-27. https://doi.org/10. 1016/j.nano.2014.03.014.

89. Le Saux S, Aarrass H, Lai-Kee-Him J, Bron P, Armengaud J, Miotello G, Bertrand-Michel J, Dubois E, George S, Faklaris O, Devoisselle JM, Legrand P, Chopineau J, Morille M. Post-production modifications of murine mesenchymal stem cell (mMSC) derived extracellular vesicles: (EVs) and impact on their cellular interaction. Biomaterials. 2020;231: 119675. https://doi.org/10.1016/j.biomaterials.2019.119675.

90. Jafari D, Shajari S, Jafari R, Mardi N, Gomari H, Ganji F, Forouzandeh Moghadam M, Samadikuchaksaraei A. Designer exosomes: a new platform for biotechnology therapeutics. BioDrugs. 2020;34:567-86. https:// doi.org/10.1007/s40259-020-00434-X.

91. Kim MS, Haney MJ, Zhao Y, Mahajan V, Deygen I, Klyachko NL, Inskoe E, Piroyan A, Sokolsky M, Okolie O, Hingtgen SD, Kabanov AV, Batrakova EV. Development of exosome-encapsulated paclitaxel to overcome MDR in cancer cells. Nanomed Nanotechnol Biol Med. 2016;12:655-64. https://doi.org/10.1016/j.nano.2015.10.012.

92. Rayamajhi S, Aryal S. Surface functionalization strategies of extracelIular vesicles. J Mater Chem B. 2020;8:4552-69. https://doi.org/10.1039/ d0tb00744g.

93. Yang Z, Xie J, Zhu J, Kang C, Chiang C, Wang X, Wang X, Kuang T, Chen F, Chen Z, Zhang A, Yu B, Lee RJ, Teng L, Lee LJ. Functional exosomemimic for delivery of siRNA to cancer: in vitro and in vivo evaluation. J Control Release. 2016;243:160-71. https://doi.org/10.1016/j.jconrel. 2016.10.008.

94. Bachurski D, Schuldner M, Nguyen PH, Malz A, Reiners KS, Grenzi PC, Babatz F, Schauss AC, Hansen HP, Hallek M, Pogge von Strandmann E. Extracellular vesicle measurements with nanoparticle tracking analysis-an accuracy and repeatability comparison between NanoSight NS300 and ZetaView. J Extracell Vesicles. 2019;8:1596016. https://doi. org/10.1080/20013078.2019.1596016.

95. Shearn AlU, Aday S, Ben-Aicha S, Carnell-Morris P, Siupa A, Angelini GD, Clayton A, Boulanger C, Punjabi P, Emanueli C, Biglino G. Analysis of neat biofluids obtained during cardiac surgery using nanoparticle tracking analysis: methodological considerations. Front Cell Dev Biol. 2020:8:367. https://doi.org/10.3389/fcell.2020.00367.

96. Fuhrmann G, Serio A, Mazo M, Nair R, Stevens MM. Active loading into extracellular vesicles significantly improves the cellular uptake and photodynamic effect of porphyrins. J Control Release. 2015;205:35-44. https://doi.org/10.1016/j.jconrel.2014.11.029.

97. Zhang X, Xu Q, Zi Z, Liu Z, Wan C, Crisman L, Shen J, Liu X. Programmable extracellular vesicles for macromolecule delivery and genome modifications. Dev Cell. 2020;55:784-801.e789. https://doi.org/10.1016/j. devcel.2020.11.007.

98. Hung ME, Leonard JN. A platform for actively loading cargo RNA to elucidate limiting steps in EV-mediated delivery. J Extracell Vesicles. 2016:5:31027. https://doi.org/10.3402/jev.v5.31027.

99. Meyer C, Losacco J, Stickney Z, Li L, Marriott G, Lu B. Pseudotyping exosomes for enhanced protein delivery in mammalian cells. Int J Nanomed. 2017;12:3153-70. https://doi.org/10.2147/ijn.S133430.

100. Kooijmans SAA, Gitz-Francois J, Schiffelers RM, Vader P. Recombinant phosphatidylserine-binding nanobodies for targeting of extracellular vesicles to tumor cells: a plug-and-play approach. Nanoscale. 2018;10:2413-26. https://doi.org/10.1039/c7nr06966a. 
101. Smyth T, Petrova K, Payton NM, Persaud I, Redzic JS, Graner MW, SmithJones P, Anchordoquy TJ. Surface functionalization of exosomes using click chemistry. Bioconjug Chem. 2014;25:1777-84. https://doi.org/10. 1021/bc500291r.

102. Tian T, Zhang HX, He CP, Fan S, Zhu YL, Qi C, Huang NP, Xiao ZD, Lu ZH, Tannous BA, Gao J. Surface functionalized exosomes as targeted drug delivery vehicles for cerebral ischemia therapy. Biomaterials. 2018;150:137-49. https://doi.org/10.1016/j.biomaterials.2017.10.012.

103. Pham TC, Jayasinghe MK, Pham TT, Yang Y, Wei L, Usman WM, Chen H, Pirisinu M, Gong J, Kim S, Peng B, Wang W, Chan C, Ma V, Nguyen NTH, Kappei D, Nguyen XH, Cho WC, Shi J, Le MTN. Covalent conjugation of extracellular vesicles with peptides and nanobodies for targeted therapeutic delivery. J Extracell Vesicles. 2021;10: e12057. https://doi.org/10. 1002/jev2.12057.

104. Kaddour H, Panzner TD, Welch JL, Shouman N, Mohan M, Stapleton JT, Okeoma CM. Electrostatic surface properties of blood and semen extracellular vesicles: implications of sialylation and HIV-induced changes on EV internalization. Viruses. 2020. https://doi.org/10.3390/v12101117.

105. Koh E, Lee EJ, Nam GH, Hong Y, Cho E, Yang Y, Kim IS. Exosome-SIRPa, a CD47 blockade increases cancer cell phagocytosis. Biomaterials. 2017;121:121-9. https://doi.org/10.1016/j.biomaterials.2017.01.004.

106. Nie W, Wu G, Zhang J, Huang LL, Ding J, Jiang A, Zhang Y, Liu Y, Li J, Pu K, Xie HY. Responsive exosome nano-bioconjugates for synergistic cancer therapy. Angew Chem Int Ed Engl. 2020;59:2018-22. https://doi.org/10. 1002/anie.201912524

107. Fröhlich $E$. The role of surface charge in cellular uptake and cytotoxicity of medical nanoparticles. Int J Nanomed. 2012;7:5577-91. https://doi. org/10.2147/ijn.S36111.

108. Zuo B, Qi H, Lu Z, Chen L, Sun B, Yang R, Zhang Y, Liu Z, Gao X, You A, Wu L, Jing R, Zhou Q, Yin H. Alarmin-painted exosomes elicit persistent antitumor immunity in large established tumors in mice. Nat Commun. 2020;11:1790. https://doi.org/10.1038/s41467-020-15569-2.

109. Du J, Che PL, Wang ZY, Aich U, Yarema KJ. Designing a binding interface for control of cancer cell adhesion via 3D topography and metabolic oligosaccharide engineering. Biomaterials. 2011;32:5427-37. https:// doi.org/10.1016/j.biomaterials.2011.04.005.

110. Mentkowski KI, Snitzer JD, Rusnak S, Lang JK. Therapeutic potential of engineered extracellular vesicles. AAPS J. 2018;20:50. https://doi.org/10. 1208/s12248-018-0211-z.

111. Kim H, Yun N, Mun D, Kang JY, Lee SH, Park H, Park H, Joung B. Cardiacspecific delivery by cardiac tissue-targeting peptide-expressing exosomes. Biochem Biophys Res Commun. 2018;499:803-8. https://doi. org/10.1016/j.bbrc.2018.03.227.

112. Alvarez-Erviti L, Seow Y, Yin H, Betts C, Lakhal S, Wood MJ. Delivery of siRNA to the mouse brain by systemic injection of targeted exosomes. Nat Biotechnol. 2011;29:341-5. https://doi.org/10.1038/nbt.1807.

113. Wang M, Altinoglu S, Takeda YS, Xu Q. Integrating protein engineering and bioorthogonal click conjugation for extracellular vesicle modulation and intracellular delivery. PLoS ONE. 2015;10: e0141860. https://doi. org/10.1371/journal.pone.0141860.

114. Sutaria DS, Jiang J, Elgamal OA, Pomeroy SM, Badawi M, Zhu X, Pavlovicz R, Azevedo-Pouly ACP, Chalmers J, Li C, Phelps MA, Schmittgen TD. Low active loading of cargo into engineered extracellular vesicles results in inefficient miRNA mimic delivery. J Extracell Vesicles. 2017:6:1333882. https://doi.org/10.1080/20013078.2017.1333882.

115. Jeyaram A, Jay SM. Preservation and storage stability of extracellular vesicles for therapeutic applications. AAPS J. 2017;20:1. https://doi.org/ 10.1208/s12248-017-0160-y.

116. Yuan F, Li YM, Wang Z. Preserving extracellular vesicles for biomedical applications: consideration of storage stability before and after isolation. Drug Deliv. 2021;28:1501-9. https://doi.org/10.1080/10717544. 2021.1951896

117. Wu JY, Li YJ, Hu XB, Huang S, Xiang DX. Preservation of small extracellular vesicles for functional analysis and therapeutic applications: a comparative evaluation of storage conditions. Drug Deliv. 2021;28:162-70. https://doi.org/10.1080/10717544.2020.1869866.

118. Wu N, Cernysiov V, Davidson D, Song H, Tang J, Luo S, Lu Y, Qian J, Gyurova IE, Waggoner SN, Trinh VQ, Cayrol R, Sugiura A, McBride HM, Daudelin JF, Labrecque N, Veillette A. Critical role of lipid scramblase TMEM16F in phosphatidylserine exposure and repair of plasma membrane after pore formation. Cell Rep. 2020;30:1129-1140.e1125. https://doi.org/10.1016/j.celrep.2019.12.066.

119. Ullah M, Liu DD, Thakor AS. Mesenchymal stromal cell homing: mechanisms and strategies for improvement. iscience. 2019;15:421-38. https://doi.org/10.1016/j.isci.2019.05.004.

120. Altanerova U, Jakubechova J, Benejova K, Priscakova P, Pesta M, Pitule P, Topolcan O, Kausitz J, Zduriencikova M, Repiska V, Altaner C. Prodrug suicide gene therapy for cancer targeted intracellular by mesenchymal stem cell exosomes. Int J Cancer. 2019;144:897-908. https://doi.org/10. 1002/ijc.31792.

121. Tkach $\mathrm{M}$, Théry C. Communication by extracellular vesicles: where we are and where we need to go. Cell. 2016;164:1226-32. https://doi.org/ 10.1016/j.cell.2016.01.043.

122. Niu W, Xiao Q, Wang X, Zhu J, Li J, Liang X, Peng Y, Wu C, Lu R, Pan Y, Luo J, Zhong $X$, He H, Rong Z, Fan JB, Wang Y. A Biomimetic drug delivery system by integrating grapefruit extracellular vesicles and doxorubicinloaded heparin-based nanoparticles for glioma therapy. Nano Lett. 2021;21:1484-92. https://doi.org/10.1021/acs.nanolett.0c04753.

123. Yong T, Zhang X, Bie N, Zhang H, Zhang X, Li F, Hakeem A, Hu J, Gan L, Santos HA, Yang $X$. Tumor exosome-based nanoparticles are efficient drug carriers for chemotherapy. Nat Commun. 2019;10:3838. https:// doi.org/10.1038/s41467-019-11718-4.

124. Shen J, Hu Y, Putt KS, Singhal S, Han H, Visscher DW, Murphy LM, Low PS Assessment of folate receptor alpha and beta expression in selection of lung and pancreatic cancer patients for receptor targeted therapies. Oncotarget. 2018;9:4485-95. https://doi.org/10.18632/oncotarget. 23321.

125. Feng C, Xiong Z, Wang C, Xiao W, Xiao H, Xie K, Chen K, Liang H, Zhang $\mathrm{X}$, Yang $\mathrm{H}$. Folic acid-modified Exosome-PH2O enhances the efficiency of therapy via modulation of the tumor microenvironment and directly inhibits tumor cell metastasis. Bioact Mater. 2021;6:963-74. https://doi. org/10.1016/j.bioactmat.2020.09.014.

126. Jiang P, Li X, Thompson CB, Huang Z, Araiza F, Osgood R, Wei G, Feldmann M, Frost Gl, Shepard HM. Effective targeting of the tumor microenvironment for cancer therapy. Anticancer Res. 2012;32:1203-12.

127. Stern R, Jedrzejas MJ. Hyaluronidases: their genomics, structures, and mechanisms of action. Chem Rev. 2006;106:818-39. https://doi.org/10. $1021 / \mathrm{cr} 050247 \mathrm{k}$

128. Wong KM, Horton KJ, Coveler AL, Hingorani SR, Harris WP. Targeting the tumor stroma: the biology and clinical development of pegylated recombinant human hyaluronidase (PEGPH20). Curr Oncol Rep. 2017:19:47. https://doi.org/10.1007/s11912-017-0608-3.

129. Zhang J, Yuan ZF, Wang Y, Chen WH, Luo GF, Cheng SX, Zhuo RX, Zhang $X Z$. Multifunctional envelope-type mesoporous silica nanoparticles for tumor-triggered targeting drug delivery. J Am Chem Soc. 2013;135:5068-73. https://doi.org/10.1021/ja312004m.

130. Wu P, Zhang B, Ocansey DKW, Xu W, Qian H. Extracellular vesicles: a bright star of nanomedicine. Biomaterials. 2020. https://doi.org/10. 1016/j.biomaterials.2020.120467.

131. Teng F, Fussenegger M. Shedding light on extracellular vesicle biogenesis and bioengineering. Adv Sci (Weinheim, Baden-Wurttemberg Germany). 2020;8:2003505. https://doi.org/10.1002/advs.202003505.

132. Campanella C, Carusobavisotto C, Logozzi M, Marinogammazza A, Mizzoni D, Cappello F, Fais S. On the choice of the extracellular vesicles for therapeutic purposes. Int J Mol Sci. 2019. https://doi.org/10.3390/ijms2 0020236.

133. Weaver BA. How taxol/paclitaxel kills cancer cells. Mol Biol Cell. 2014;25:2677-81. https://doi.org/10.1091/mbc.E14-04-0916.

134. Saari H, Lázaro-lbáñez E, Viitala T, Vuorimaa-Laukkanen E, Siljander P, Yliperttula M. Microvesicle- and exosome-mediated drug delivery enhances the cytotoxicity of Paclitaxel in autologous prostate cancer cells. J Control Release. 2015;220:727-37. https://doi.org/10.1016/j.jconr el.2015.09.031.

135. Li Y, Gao Y, Gong C, Wang Z, Xia Q, Gu F, Hu C, Zhang L, Guo H, Gao S. A33 antibody-functionalized exosomes for targeted delivery of doxorubicin against colorectal cancer. Nanomed Nanotechnol Biol Med. 2018;14:1973-85. https://doi.org/10.1016/j.nano.2018.05.020.

136. Ye Z, Zhang T, He W, Jin H, Liu C, Yang Z, Ren J. Methotrexate-loaded extracellular vesicles functionalized with therapeutic and targeted peptides for the treatment of glioblastoma multiforme. ACS Appl Mater Interfaces. 2018;10:12341-50. https://doi.org/10.1021/acsami.7b18135. 
137. Li YJ, Wu JY, Wang JM, Hu XB, Cai JX, Xiang DX. Gemcitabine loaded autologous exosomes for effective and safe chemotherapy of pancreatic cancer. Acta Biomater. 2020;101:519-30. https://doi.org/10.1016/j. actbio.2019.10.022.

138. Waters AM, Der CJ. KRAS: the critical driver and therapeutic target for pancreatic cancer. Cold Spring Harb Perspect Med. 2018. https://doi. org/10.1101/cshperspect.a031435.

139. Kamerkar S, LeBleu VS, Sugimoto H, Yang S, Ruivo CF, Melo SA, Lee JJ, Kalluri R. Exosomes facilitate therapeutic targeting of oncogenic KRAS in pancreatic cancer. Nature. 2017;546:498-503. https://doi.org/10. 1038/nature22341.

140. Wang X, Zhang H, Bai M, Ning T, Ge S, Deng T, Liu R, Zhang L, Ying $\mathrm{G}, \mathrm{Ba}$ Y. Exosomes serve as nanoparticles to deliver anti-miR-214 to reverse chemoresistance to cisplatin in gastric cancer. Mol Therapy. 2018;26:774-83. https://doi.org/10.1016/j.ymthe.2018.01.001.

141. Kobayashi M, Sawada K, Miyamoto M, Shimizu A, Yamamoto M, Kinose Y, Nakamura K, Kawano M, Kodama M, Hashimoto K, Kimura T. Exploring the potential of engineered exosomes as delivery systems for tumorsuppressor microRNA replacement therapy in ovarian cancer. Biochem Biophys Res Commun. 2020;527:153-61. https://doi.org/10.1016/j.bbrc. 2020.04.076.

142. Liang G, Zhu Y, Ali DJ, Tian T, Xu H, Si K, Sun B, Chen B, Xiao Z. Engineered exosomes for targeted co-delivery of miR-21 inhibitor and chemotherapeutics to reverse drug resistance in colon cancer. J Nanobiotechnol. 2020. https://doi.org/10.1186/s12951-019-0563-2.

143. Kim SM, Yang Y, Oh SJ, Hong Y, Seo M, Jang M. Cancer-derived exosomes as a delivery platform of CRISPR/Cas9 confer cancer cell tropism-dependent targeting. J Control Release. 2017;266:8-16. https:// doi.org/10.1016/j.jconrel.2017.09.013.

144. Usman WM, Pham TC, Kwok YY, Vu LT, Ma V, Peng B, Chan YS, Wei L, Chin SM, Azad A, He AB, Leung AYH, Yang M, Shyh-Chang N, Cho WC, Shi J, Le MTN. Efficient RNA drug delivery using red blood cell extracelIular vesicles. Nat Commun. 2018;9:2359. https://doi.org/10.1038/ s41467-018-04791-8.

145. Chiocca EA. Oncolytic viruses, nature reviews. Cancer. 2002;2:938-50. https://doi.org/10.1038/nrc948.

146. Garofalo M, Saari H, Somersalo P, Crescenti D, Kuryk L, Aksela L, Capasso C, Madetoja M, Koskinen K, Oksanen T, Mäkitie A, Jalasvuori M, Cerullo V Ciana P, Yliperttula M. Antitumor effect of oncolytic virus and paclitaxel encapsulated in extracellular vesicles for lung cancer treatment. J Control Release. 2018;283:223-34. https://doi.org/10.1016/j.jconrel.2018.05. 015.

147. Tan Y, Salkhordeh M, Wang JP, McRae A, Souza-Moreira L, Mclntyre L, Stewart DJ, Mei SHJ. Thawed mesenchymal stem cell product shows comparable immunomodulatory potency to cultured cells in vitro and in polymicrobial septic animals. Sci Rep. 2019;9:18078. https://doi.org/ 10.1038/s41598-019-54462-X.

148. Ren W, Hou J, Yang C, Wang H, Wu S, Wu Y, Zhao X, Lu C. Extracellular vesicles secreted by hypoxia pre-challenged mesenchymal stem cells promote non-small cell lung cancer cell growth and mobility as well as macrophage M2 polarization via miR-21-5p delivery. J Exp Clin Cancer Res CR. 2019;38:62. https://doi.org/10.1186/s13046-019-1027-0.

149. Rani S, Ryan AE, Griffin MD, Ritter T. Mesenchymal stem cell-derived extracellular vesicles: toward cell-free therapeutic applications. Mol Therapy. 2015;23:812-23. https://doi.org/10.1038/mt.2015.44.

150. Dabrowska S, Andrzejewska A, Lukomska B, Janowski M. Neuroinflammation as a target for treatment of stroke using mesenchymal stem cells and extracellular vesicles. J Neuroinflammation. 2019;16:178. https://doi.org/10.1186/s12974-019-1571-8.

151. Wei H, Chen J, Wang S, Fu F, Zhu X, Wu C, Liu Z, Zhong G, Lin J. A nanodrug consisting of doxorubicin and exosome derived from mesenchymal stem cells for osteosarcoma treatment in vitro. Int J Nanomed. 2019;14:8603-10. https://doi.org/10.2147/IJN.S218988.

152. . Yu L, Gui S, Liu Y, Qiu X, Zhang G (2019) Exosomes derived from microRNA-199a-overexpressing mesenchymal stem cells inhibit glioma progression by down-regulating AGAP2.

153. Zhou Y, Yamamoto Y, Takeshita F, Yamamoto T, Xiao Z, Ochiya T. Delivery of miR-424-5p via extracellular vesicles promotes the apoptosis of MDA-MB-231 TNBC cells in the tumor microenvironment. Int J Mol Sci. 2021. https://doi.org/10.3390/ijms22020844.
154. Zhou W, Zhou Y, Chen X, Ning T, Chen H, Guo Q, Zhang Y, Liu P, Zhang Y, Li C, Chu Y, Sun T, Jiang C. Pancreatic cancer-targeting exosomes for enhancing immunotherapy and reprogramming tumor microenvironment. Biomaterials. 2020;268: 120546. https://doi.org/10.1016/j.bioma terials.2020.120546.

155. Pontecorvi G, Bellenghi M, Puglisi R, Carè A, Mattia G. Tumor-derived extracellular vesicles and microRNAs: functional roles, diagnostic, prognostic and therapeutic options. Cytokine Growth Factor Rev. 2020;51:75-83. https://doi.org/10.1016/j.cytogfr.2019.12.010.

156. Rak J, Guha A. Extracellular vesicles-vehicles that spread cancer genes. BioEssays News Rev Mol Cell Dev Biol. 2012;34:489-97. https://doi.org/ 10.1002/bies.201100169.

157. Maacha S, Bhat AA, Jimenez L, Raza A, Haris M, Uddin S, Grivel JC. Extracellular vesicles-mediated intercellular communication: roles in the tumor microenvironment and anti-cancer drug resistance. Mol Cancer. 2019;18:55. https://doi.org/10.1186/s12943-019-0965-7.

158. Patel N, Kommineni N, Surapaneni SK, Kalvala A, Yaun X, Gebeyehu A, Arthur P, Duke LC, York SB, Bagde A, Meckes DG Jr, Singh M. Cannabidiol loaded extracellular vesicles sensitize triple-negative breast cancer to doxorubicin in both in-vitro and in vivo models. Int J Pharm. 2021;607: 120943. https://doi.org/10.1016/j.ijpharm.2021.120943.

159. Koyama Y, Ito T, Hasegawa A, Eriguchi M, Inaba T, Ushigusa T, Sugiura K. Exosomes derived from tumor cells genetically modified to express Mycobacterium tuberculosis antigen: a novel vaccine for cancer therapy. Biotechnol Lett. 2016;38:1857-66. https://doi.org/10.1007/ s10529-016-2185-1.

160. Li S, Wu Y, Ding F, Yang J, Li J, Gao X, Zhang C, Feng J. Engineering macrophage-derived exosomes for targeted chemotherapy of triplenegative breast cancer. Nanoscale. 2020;12:10854-62. https://doi.org/ 10.1039/d0nr00523a.

161. Kowal J, Tkach M. Dendritic cell extracellular vesicles. Int Rev Cell Mol Biol. 2019;349:213-49. https://doi.org/10.1016/bs.ircmb.2019.08.005.

162. Fernández-Delgado I, Calzada-Fraile D, Sánchez-Madrid F. Immune regulation by dendritic cell extracellular vesicles in cancer immunotherapy and vaccines. Cancers. 2020. https://doi.org/10.3390/cance rs12123558.

163. Lu Z, Zuo B, Jing R, Gao X, Rao Q, Liu Z, Qi H, Guo H, Yin H. Dendritic cell-derived exosomes elicit tumor regression in autochthonous hepatocellular carcinoma mouse models. J Hepatol. 2017;67:739-48. https:// doi.org/10.1016/j.jhep.2017.05.019.

164. Damo M, Wilson DS, Simeoni E, Hubbell JA. TLR-3 stimulation improves anti-tumor immunity elicited by dendritic cell exosome-based vaccines in a murine model of melanoma. Sci Rep. 2015;5:17622. https://doi.org/ 10.1038/srep17622.

165. Fu W, Lei C, Liu S, Cui Y, Wang C, Qian K, Li T, Shen Y, Fan X, Lin F, Ding M, Pan M, Ye X, Yang Y, Hu S. CAR exosomes derived from effector CAR-T cells have potent antitumour effects and low toxicity. Nat Commun. 2019;10:4355. https://doi.org/10.1038/s41467-019-12321-3.

166. Di Pace AL, Tumino N, Besi F, Alicata C, Conti LA, Munari E, Maggi E, Vacca P, Moretta L. Characterization of human NK cell-derived exosomes: role of DNAM1 receptor in exosome-mediated cytotoxicity against tumor. Cancers. 2020. https://doi.org/10.3390/cancers120 30661.

167. Wang G, Hu W, Chen H, Shou X, Ye T, Xu Y. Cocktail strategy based on NK cell-derived exosomes and their biomimetic nanoparticles for dual tumor therapy. Cancers. 2019. https://doi.org/10.3390/cancers111 01560.

168. Ji K, Fan M, Huang D, Sun L, Li B, Xu R, Zhang J, Shao X, Chen Y. Clodronate-nintedanib-loaded exosome-liposome hybridization enhances the liver fibrosis therapy by inhibiting Kupffer cell activity. Biomater Sci. 2021. https://doi.org/10.1039/d1bm01663f.

169. Safari B, Aghazadeh M, Davaran S, Roshangar L. Exosome-loaded hydrogels: a new cell-free therapeutic approach for skin regeneration. Eur J Pharm Biopharm. 2021. https://doi.org/10.1016/j.ejpb.2021.11.002.

170. Lord CJ, Ashworth A. The DNA damage response and cancer therapy. Nature. 2012;481:287-94. https://doi.org/10.1038/nature10760.

171. Duijf PHG, Nanayakkara D, Nones K, Srihari S, Kalimutho M, Khanna KK. Mechanisms of genomic instability in breast cancer. Trends Mol Med. 2019;25:595-611. https://doi.org/10.1016/j.molmed.2019.04.004.

172. Huang L, Chen X, Dasgupta C, Chen W, Song R, Wang C, Zhang L. Foetal hypoxia impacts methylome and transcriptome in developmental 
programming of heart disease. Cardiovasc Res. 2019;115:1306-19. https://doi.org/10.1093/cvr/cvy277.

173. Le Saux S, Aubert-Pouessel A, Mohamed KE, Martineau P, Guglielmi L, Devoisselle JM, Legrand P, Chopineau J, Morille M. Interest of extracellular vesicles in regards to lipid nanoparticle based systems for intracellular protein delivery. Adv Drug Deliv Rev. 2021;176: 113837. https://doi. org/10.1016/j.addr.2021.113837.

174. Oliva N, Conde J, Wang K, Artzi N. Designing hydrogels for on-demand therapy. Acc Chem Res. 2017;50:669-79. https://doi.org/10.1021/acs. accounts.6b00536.

175. Chehreghanianzabi Y, Auner G, Shi T, Dietz P, Bou-AklT, Markel DC, Ren W. Impacts of compacting methods on the delivery of erythromycin and vancomycin from calcium polyphosphate hydrogel matrices. J Biomed Mater Res B Appl Biomater. 2021. https://doi.org/10.1002/ jbm.b.34917.

176. Tsou YH, Khoneisser J, Huang PC, Xu X. Hydrogel as a bioactive material to regulate stem cell fate. Bioact Mater. 2016;1:39-55. https://doi.org/ 10.1016/j.bioactmat.2016.05.001.

177. Pishavar E, Luo H, Naserifar M, Hashemi M, Toosi S, Atala A, Ramakrishna S, Behravan J. Advanced hydrogels as exosome delivery systems for osteogenic differentiation of MSCs: application in bone regeneration. Int J Mol Sci. 2021. https://doi.org/10.3390/ijms22126203.

178. Ghosh K, Shu XZ, Mou R, Lombardi J, Prestwich GD, Rafailovich MH, Clark RA. Rheological characterization of in situ cross-linkable hyaluronan hydrogels. Biomacromol. 2005;6:2857-65. https://doi.org/10.1021/ bm050361c.

179. Qin Y, Wang L, Gao Z, Chen G, Zhang C. Bone marrow stromal/stem cell-derived extracellular vesicles regulate osteoblast activity and differentiation in vitro and promote bone regeneration in vivo. Sci Rep. 2016;6:21961. https://doi.org/10.1038/srep21961.

180. Tan G, Zhong Y, Yang L, Jiang Y, Liu J, Ren F. A multifunctional MOFbased nanohybrid as injectable implant platform for drug synergistic oral cancer therapy. Chem Eng J. 2020. https://doi.org/10.1016/j.cej. 2020.124446.

181. Yang J, Chen Z, Pan D, Li H, Shen J. Umbilical cord-derived mesenchymal stem cell-derived exosomes combined pluronic F127 hydrogel promote chronic diabetic wound healing and complete skin regeneration. Int J Nanomed. 2020;15:5911-26. https://doi.org/10.2147/ijn.S2491 29.

182. Hu CM, Zhang L. Nanoparticle-based combination therapy toward overcoming drug resistance in cancer. Biochem Pharmacol. 2012:83:1104-11. https://doi.org/10.1016/j.bcp.2012.01.008.

183. Ishida T, Harashima H, Kiwada H. Liposome clearance. Biosci Rep. 2002;22:197-224. https://doi.org/10.1023/a:1020134521778.

184. Pattni BS, Chupin WV, Torchilin VP. New developments in liposomal drug delivery. Chem Rev. 2015;115:10938-66. https://doi.org/10.1021/acs. chemrev. 5 b00046.

185. Gibis M, Rahn N, Weiss J. Physical and oxidative stability of uncoated and chitosan-coated liposomes containing grape seed extract. Pharmaceutics. 2013;5:421-33. https://doi.org/10.3390/pharmaceutic55030421.

186. Krajewska JB, Bartoszek A, Fichna J. New trends in liposome-based drug delivery in colorectal cancer. Mini Rev Med Chem. 2019;19:3-11. https://doi.org/10.2174/1389557518666180903150928.

187. Derycke AS, de Witte PA. Liposomes for photodynamic therapy. Adv Drug Deliv Rev. 2004;56:17-30. https://doi.org/10.1016/j.addr.2003.07. 014.

188. Reyes A, Corrales N, Gálvez NMS, Bueno SM, Kalergis AM, González PA. Contribution of hypoxia inducible factor-1 during viral infections. Virulence. 2020;11:1482-500. https://doi.org/10.1080/21505594.2020. 1836904.

189. Maeki M, Kimura N, Sato Y, Harashima H, Tokeshi M. Advances in microfluidics for lipid nanoparticles and extracellular vesicles and applications in drug delivery systems. Adv Drug Deliv Rev. 2018;128:84-100. https://doi.org/10.1016/j.addr.2018.03.008.

190. Elkhoury K, Koçak P, Kang A, Arab-Tehrany E, Ellis Ward J, Shin SR. Engineering smart targeting nanovesicles and their combination with hydrogels for controlled drug delivery. Pharmaceutics. 2020. https://doi. org/10.3390/pharmaceutics12090849.

191. Wu M, Ouyang Y, Wang Z, Zhang R, Huang PH, Chen C, Li H, Li P, Quinn D, Dao M, Suresh S, Sadovsky Y, Huang TJ. Isolation of exosomes from whole blood by integrating acoustics and microfluidics. Proc Natl Acad Sci USA. 2017;114:10584-9. https://doi.org/10.1073/pnas.1709210114.

192. Liang LG, Kong MQ, Zhou S, Sheng YF, Wang P, Yu T, Inci F, Kuo WP, Li LJ, Demirci U, Wang S. An integrated double-filtration microfluidic device for isolation, enrichment and quantification of urinary extracellular vesicles for detection of bladder cancer. Sci Rep. 2017;7:46224. https:// doi.org/10.1038/srep46224.

193. Yuan Q, Yeudall WA, Lee E, Yang H. Targeted inactivation of EPS8 using dendrimer-mediated delivery of RNA interference. Int J Pharm. 2019;557:178-81. https://doi.org/10.1016/j.ijpharm.2018.12.060.

194. Yeo RW, Lai RC, Zhang B, Tan SS, Yin Y, Teh BJ, Lim SK. Mesenchymal stem cell: an efficient mass producer of exosomes for drug delivery. Adv Drug Deliv Rev. 2013;65:336-41. https://doi.org/10.1016/j.addr. 2012.07.001.

195. Ankrum JA, Ong JF, Karp JM. Mesenchymal stem cells: immune evasive, not immune privileged. Nat Biotechnol. 2014;32:252-60. https://doi. org/10.1038/nbt.2816.

196. Greening DW, Xu R, Ji H, Tauro BJ, Simpson RJ. A protocol for exosome isolation and characterization: evaluation of ultracentrifugation, density-gradient separation, and immunoaffinity capture methods. Methods Mol Biol (Clifton, NJ). 2015;1295:179-209. https://doi.org/10. 1007/978-1-4939-2550-6_15.

197. Dong L, Zieren RC, Horie K, Kim CJ, Mallick E, Jing Y, Feng M, Kuczler MD, Green J, Amend SR, Witwer KW, de Reijke TM, Cho YK, Pienta KJ, Xue W. Comprehensive evaluation of methods for small extracellular vesicles separation from human plasma, urine and cell culture medium. J Extracell Vesicles. 2020;10: e12044. https://doi.org/10.1002/jev2.12044.

198. Lozano-Ramos I, Bancu I, Oliveira-Tercero A, Armengol MP, MenezesNeto A, Del Portillo HA, Lauzurica-Valdemoros R, Borràs FE. Size-exclusion chromatography-based enrichment of extracellular vesicles from urine samples. J Extracell Vesicles. 2015:4:27369. https://doi.org/10. 3402/jev.v4.27369.

199. Nordin JZ, Lee Y, Vader P, Mäger I, Johansson HJ, Heusermann W, Wiklander OP, Hällbrink M, Seow Y, Bultema JJ, Gilthorpe J, Davies T, Fairchild PJ, Gabrielsson S, Meisner-Kober NC, Lehtiö J, Smith CI, Wood MJ, El Andaloussi S. Ultrafiltration with size-exclusion liquid chromatography for high yield isolation of extracellular vesicles preserving intact biophysical and functional properties. Nanomed Nanotechnol Biol Med. 2015;11:879-83. https://doi.org/10.1016/j.nano.2015.01.003.

200. Li M, Lou D, Chen J, Shi K, Wang Y, Zhu Q, Liu F, Zhang Y. Deep dive on the proteome of salivary extracellular vesicles: comparison between ultracentrifugation and polymer-based precipitation isolation. Anal Bioanal Chem. 2021;413:365-75. https://doi.org/10.1007/ s00216-020-03004-W.

201. Yang F, Liao X, Tian Y, Li G. Exosome separation using microfluidic systems: size-based, immunoaffinity-based and dynamic methodologies. Biotechnol J. 2017. https://doi.org/10.1002/biot.201600699.

202. Gholizadeh S, Shehata Draz M, Zarghooni M, Sanati-Nezhad A, Ghavami $\mathrm{S}$, Shafiee H, Akbari M. Microfluidic approaches for isolation, detection, and characterization of extracellular vesicles: current status and future directions. Biosens Bioelectron. 2017;91:588-605. https://doi.org/10. 1016/j.bios.2016.12.062.

203. Tian Y, Li S, Song J, Ji T, Zhu M, Anderson GJ, Wei J, Nie G. A doxorubicin delivery platform using engineered natural membrane vesicle exosomes for targeted tumor therapy. Biomaterials. 2014;35:2383-90. https://doi.org/10.1016/j.biomaterials.2013.11.083.

204. Naseri Z, Oskuee RK, Jaafari MR, Forouzandeh Moghadam M. Exosomemediated delivery of functionally active miRNA-142-3p inhibitor reduces tumorigenicity of breast cancer in vitro and in vivo. Int J Nanomed. 2018;13:7727-47. https://doi.org/10.2147/IJN.S182384.

205. Yang Z, Shi J, Xie J, Wang Y, Sun J, Liu T, Zhao Y, Zhao X, Wang X, Ma Y, Malkoc V, Chiang C, Deng W, Chen Y, Fu Y, Kwak KJ, Fan Y, Kang C, Yin C, Rhee J, Bertani P, Otero J, Lu W, Yun K, Lee AS, Jiang W, Teng L, Kim BYS, Lee LJ. Large-scale generation of functional mRNA-encapsulating exosomes via cellular nanoporation. Nat Biomed Eng. 2020;4:69-83. https://doi.org/10.1038/s41551-019-0485-1.

206. Nasiri Kenari A, Cheng L, Hill AF. Methods for loading therapeutics into extracellular vesicles and generating extracellular vesicles mimeticnanovesicles. Methods (San Diego, Calif). 2020;177:103-13. https://doi. org/10.1016/j.ymeth.2020.01.001. 
207. Lamichhane TN, Jeyaram A, Patel DB, Parajuli B, Livingston NK, Arumugasaamy N, Schardt JS, Jay SM. Oncogene knockdown via active loading of small RNAs into extracellular vesicles by sonication. Cell Mol Bioeng. 2016;9:315-24. https://doi.org/10.1007/s12195-016-0457-4.

208. Sancho-Albero M, Encabo-Berzosa MDM, Beltrán-Visiedo M, FernándezMessina L, Sebastián V, Sánchez-Madrid F, Arruebo M, Santamaría J, Martín-Duque P. Efficient encapsulation of theranostic nanoparticles in cell-derived exosomes: leveraging the exosomal biogenesis pathway to obtain hollow gold nanoparticle-hybrids. Nanoscale. 2019;11:18825-36. https://doi.org/10.1039/c9nr06183e.

209. Nakase I, Futaki S. Combined treatment with a pH-sensitive fusogenic peptide and cationic lipids achieves enhanced cytosolic delivery of exosomes. Sci Rep. 2015;5:10112. https://doi.org/10.1038/srep10112.

210. Zhu Q, Ling X, Yang Y, Zhang J, Li Q, Niu X, Hu G, Chen B, Li H, Wang Y, Deng Z. Embryonic stem cells-derived exosomes endowed with targeting properties as chemotherapeutics delivery vehicles for glioblastoma therapy. Adv Sci. 2019;6:1801899. https://doi.org/10.1002/advs.20180 1899.

211. Wan S, Zhang L, Wang S, Liu Y, Wu C, Cui C, Sun H, Shi M, Jiang Y, Li L, Qiu L, Tan W. Molecular recognition-based DNA nanoassemblies on the surfaces of nanosized exosomes. J Am Chem Soc. 2017;139:5289-92. https://doi.org/10.1021/jacs.7b00319.

212. Ohno S, Takanashi M, Sudo K, Ueda S, Ishikawa A, Matsuyama N, Fujita K, Mizutani T, Ohgi T, Ochiya T, Gotoh N, Kuroda M. Systemically injected exosomes targeted to EGFR deliver antitumor microRNA to breast cancer cells. Mol Therapy. 2013;21:185-91. https://doi.org/10.1038/mt. 2012.180.

213. Pi F, Binzel DW, Lee TJ, Li Z, Sun M, Rychahou P, Li H, Haque F, Wang S, Croce CM, Guo B, Evers BM, Guo P. Nanoparticle orientation to control RNA loading and ligand display on extracellular vesicles for cancer regression. Nat Nanotechnol. 2018;13:82-9. https://doi.org/10.1038/ s41565-017-0012-z.

214. Pomatto MAC, Bussolati B, D'Antico S, Ghiotto S, Tetta C, Brizzi MF, Camussi G. Improved loading of plasma-derived extracellular vesicles to encapsulate antitumor miRNAs. Mol Therapy Methods Clin Dev. 2019;13:133-44. https://doi.org/10.1016/j.omtm.2019.01.001.

215. Tu Y, Dong Y, Wang $K$, Shen $S$, Yuan $Y$, Wang J. Intercellular delivery of bioorthogonal chemical receptors for enhanced tumor targeting and penetration. Biomaterials. 2020;259: 120298. https://doi.org/10.1016/j. biomaterials.2020.120298.

216. Greco KA, Franzen CA, Foreman KE, Flanigan RC, Kuo PC, Gupta GN. PLK-1 silencing in bladder cancer by siRNA delivered with exosomes. Urology. 2016;91:241.e241-247. https://doi.org/10.1016/j.urology.2016. 01.028 .

217. Hadla M, Palazzolo S, Corona G, Caligiuri I, Canzonieri V, Toffoli G, Rizzolio F. Exosomes increase the therapeutic index of doxorubicin in breast and ovarian cancer mouse models. Nanomedicine (Lond). 2016;11:2431-41. https://doi.org/10.2217/nnm-2016-0154.

\section{Publisher's Note}

Springer Nature remains neutral with regard to jurisdictional claims in published maps and institutional affiliations.

Ready to submit your research? Choose BMC and benefit from:

- fast, convenient online submission

- thorough peer review by experienced researchers in your field

- rapid publication on acceptance

- support for research data, including large and complex data types

- gold Open Access which fosters wider collaboration and increased citations

- maximum visibility for your research: over 100M website views per year

At BMC, research is always in progress.

Learn more biomedcentral.com/submissions 